Original paper

\title{
High-pressure metabasic rocks from the Kutná Hora Complex: geological position and petrology of exotic lithologies along the segmented Moldanubian margin, Bohemian Massif
}

\author{
Veronika ŠTĚDRÁ ${ }^{* *}$, Radmila NAHODILOVÁ ${ }^{1,2}$ \\ ${ }^{1}$ Czech Geological Survey, Klárov 3, 11821 Prague 1, Czech Republic; veronika.stedra@geology.cz \\ ${ }^{2}$ Institute of Petrology and Structural Geology, Charles University, Albertov 6, 12843 Prague 2, Czech Republic \\ ${ }^{*}$ Corresponding author
}

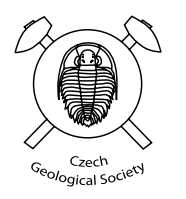

New occurrences of high-pressure metabasites in the Kutná Hora Unit $(\mathrm{KHC})$ are described. These HP rocks include
eclogites $( \pm \mathrm{Ky}$ ), Cpx-Grt amphibolites, metagabbros and Cpx-bearing granulites. All the eclogite samples studied are
formed of well-preserved HP mineral assemblages with variable degree of subsequent metamorphic overprint.
Eclogites from the inner part of the KHC (Roztěž, Bořetice) mostly had a Mg-rich tholeiitic protolith. Chemical, mi-
neralogical and metamorphic data reveal that these eclogites are petrologically similar to the eclogite samples from
the better known Běstvina Unit. Eclogites from Bořetice, Poličany and Roztěž preserve relict mineral assemblage
from a pre-eclogite stage, enclosed in garnet with prograde zoning pattern. They bear mineralogical evidence of a very
high-pressure history, even substantially higher (maximum $8.4 \mathrm{wt}$. \% of $\mathrm{Na}_{2} \mathrm{O}$ in $\mathrm{Cpx}, \mathrm{P} \sim 4.3 \mathrm{GPa}$ ) than the previously
described eclogites from Spačice and Úhrov in the Běstvina Unit.
A set of three eclogites from the northern margin of the Moldanubian Zone south of Chotěboř was used for comparison
(Bída, Borovský Creek, Krátká Ves). They preserve also a peak pressure record that corresponds to minimum pressures
above 2.0 GPa.
Better understanding of regional relationships amongst the discussed units can be achieved only using isotopic and
geochronological data.

Keywords: eclogites, high pressure metamorphism, petrology, Kutná Hora Complex, Bohemian Massif

Received: 26 March 2009; accepted 18 June 2009; handling editor: E. Jelinek

The online version of this article (http://dx.doi.org/10.3190/jgeosci.047) contains supplementary electronic material.

\section{Introduction}

Published and unpublished reports dealing with the contact of the Moldanubian Zone (MZ) with the Kutná HoraSvratka Super-unit (KHS) provide an increasing number of geological arguments for regional interpretations. The latter stem from correlations of local units with other well described crustal segments, e.g., in Polish Sudetes (Mazur et al. 2005). A majority of petrological studies have been focused on the eastern parts of the boundary east of the Prribyslav mylonite zone and the Železné Hory Mts., while the western Kutná Hora Complex (KHC) remained of only limited interest. Fišera $(1977,1981)$ endured detailed studies of some parts in this area; his fieldwork remains an important contribution to the mapping of the territory and was also one of the stimuli triggering initiation of this study.

The KHC is a complex unit whose internal highgrade Malín and Běstvina units were defined by Losert (1967), and tectonometamorphic subdivision was proposed by Synek and Oliveriová (1993). The small, but petrologically attractive Běstvina Unit in the eastern tip of the KHC preserves a variegated collage of highgrade metamorphic lower-crustal and mantle rock assemblages, including granulites, eclogites, pyroxenites, spinel and garnet peridotites. Both the units display petrological and metamorphic features common with most of the inner KHC area, geological setting of which is not sufficiently explained so far. This contribution presents results of study of several new high-pressure metabasites occurrences from the KHC undertaken in 2003-2008.

The main aim is to summarize new geological data on the KHC metabasites, and to gather an evidence for HP/UHP metamorphism in the central part of the KHC. In addition, the new petrological, mineralogical and whole-rock geochemical data support interpretation of the KHC as an independent tectonic segment of the Kutná Hora-Svratka Super-unit, demonstrate the differences in metamorphic evolution between the KHC and the adjacent eastern margin of the Moldanubian Zone as well as the classical occurrence of the Gföhl Unit in the south-eastern part of the MZ (Matte et al. 1990; Medaris et al. 2005; Schulmann et al. 2005). 


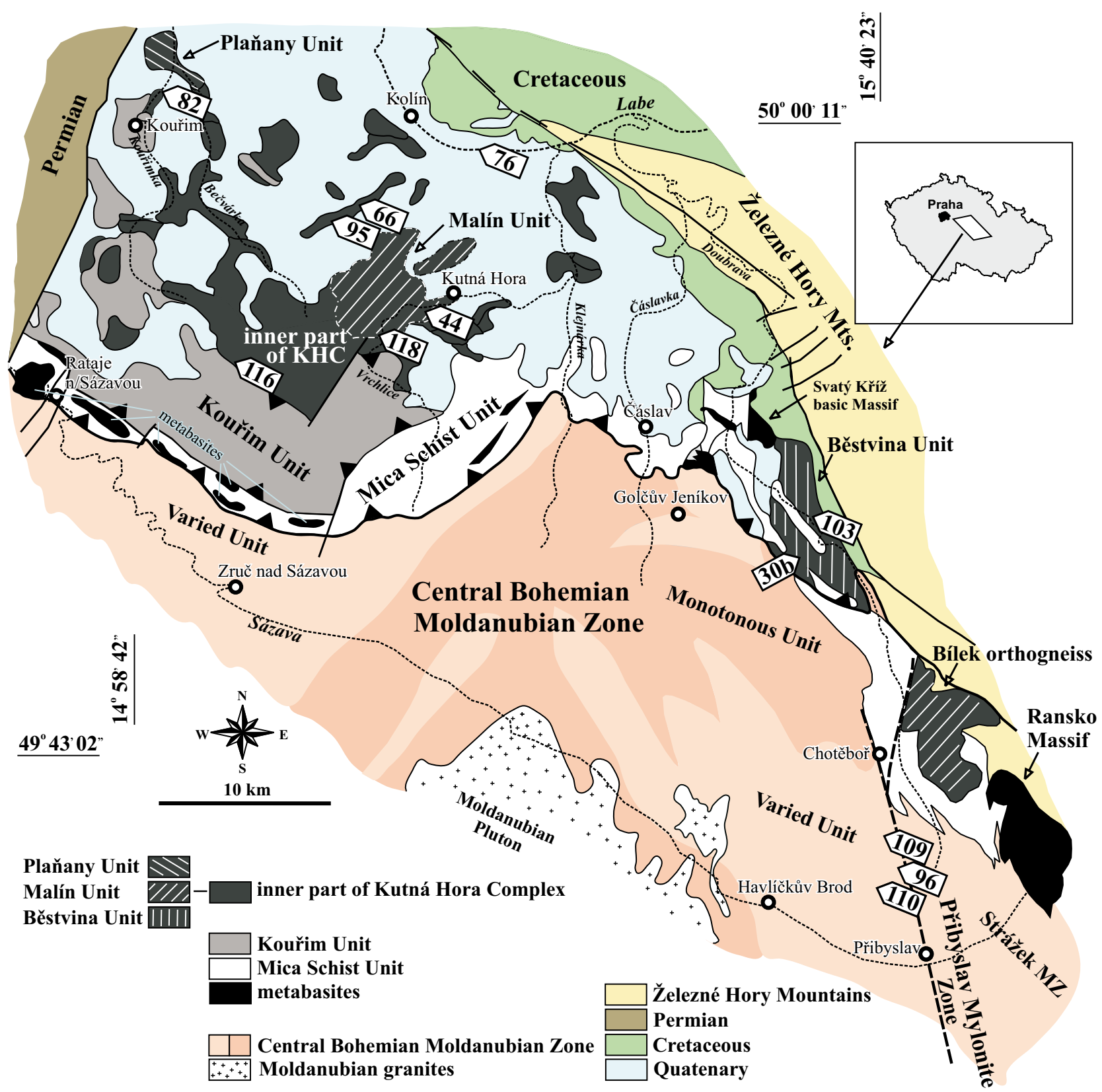

Fig. 1 Geological scheme of the Kutná Hora Complex and Moldanubian Zone with location of the sampled high-pressure rocks. Based on Synek and Oliveriová (1993), modified after Losert (1967) and Štědrá ed. (2009). Labelled localities correspond to numbers of the "KMV" rock sample series (see Tab. 1).

\section{Geological setting of the KHC}

The most recent tectonic and structural subdivision of the KHC was proposed by Synek and Oliveriová (1993). Recent mapping and related field work enabled close examination of the distribution of the exposed rock bodies which, on the relevant scale, do not always fit with the geological scheme published by these authors. Therefore, this chapter provides adjusted version of the geological division of the KHC.

Going from the southern boundary with the Varied Unit of the Moldanubian Zone northwards, the Kutná Hora Complex (Fig. 1) consists of four units.

1. Almost continuous outer Mica Schist Unit separates the KHC from the sillimanite-in isograd of the Varied Unit. The dominant mica schists enclose numer- 
ous lenses of amphibolites, whose metamorphic grade does not exceed the garnet-amphibolite grade and most of which indicate a calc-alkaline source (Kachlík 1999). The penetrative shear deformation accompanied by relatively low-grade metamorphism also overprinted the rocks of the neighbouring Varied Unit, so that its contact is difficult to detect at present. However, the presence of medium-grade varied marine sedimentary members like marbles, calc-alkaline amphibolites, and calc-silicates can be a lithological indication of the Varied MZ paraautochthon.

Synek and Oliveriová (1993) classified the outer Mica Schist Zone a part of the KHC on basis of tectonic and structural characteristics without respect to its lithological overlap with the Varied Unit. The Mica Schist Unit continues to the SE along the Běstvina Unit almost as far as the Ransko Massif, in places being strongly tectonically reduced.

2. A nappe-like unit north of the Mica Schist Unit consisting of mineralogically simple, metaigneous rock assemblage was defined as a Kouřim Nappe (Synek and Oliveriová 1993). This unit definitely differs from other segments of the KHC; it is formed exclusively by quartzo-feldspathic orthogneiss and migmatites, which do not contain any index alumosilicate minerals or garnet but do contain micas. It also differs in its structural characteristics, as it exhibits strong refoliation, rotation of older planar elements into the predominating late trend plunging to the $\mathrm{NW}$, and dominant $\mathrm{P}-\mathrm{L}$ deformation locally passing into westerly dipping pure constrictional patterns developed in orthogneisses (see also Synek 1991). Thus, the typical coarse-grained pencil and augen orthogneisses alternate with fine-grained stromatitic muscovite and two-mica polymetamorphic migmatites with planolinear fabrics, resembling syntectonic injections of granitic melt into intensely sheared neck-zones between boudinaged older migmatitic domains. The rocks generally ascribed to the Kourim Unit form the almost homogeneous SW flank of the KHC adjacent to the outer Mica Schist Unit. In addition, they are scattered throughout the central KHC area, where they usually dip under the metabasic, migmatitic and metasedimentary rocks of the $\mathrm{KHC}$ core.

3. The third rock assemblage of the KHC forms its inner zone and partially corresponds to the high-grade units defined by Losert (1967). It is characterized by the presence of a heterogeneous mixture of kyanite-bearing garnetiferous mica schists, migmatized paragneisses, refoliated migmatites, eclogites, garnet peridotites, garnetiferous amphibolites, massive augen gneisses or banded felsic orthogneisses, and fine-grained mylonitized Ky-Grt orthogneisses. Metamorphic events in some rock types of the assemblage (kyanite-garnet migmatites, granulites and mylonitized orthogneisses) are described in a special- ized contribution (Vrána et al. this volume). This series exhibits many features in common with the Běstvina Unit at the northeastern margin of the $\mathrm{KHC}$, as was repeatedly pointed out in the literature (Pouba et al. 1987; Medaris et al. 2005, 2006; Vrána et al. 2005; Machek et al. 2006; Faryad 2009). This relatively well-exposed Běstvina Unit is separated in detailed geological maps from the main body of the KHC by younger sedimentary cover that obscures structural relationship between prevailing retrograde granulitic gneisses of the Běstvina Unit and the rest of KHC. In this work, the Běstvina Unit is discussed as an integral part of the inner part of the KHC. Eclogites from Úhrov and Spačice in the Běstvina Unit and from Dobešovice and Bečváry in the inner KHC were studied in detail by Medaris et al. (1998). Their thermobarometric data for the peak metamorphic event correspond to $1030-1200^{\circ} \mathrm{C}$ and $17-22 \mathrm{GPa}$ for kyanite eclogite from Úhrov (Medaris et al. 2006), $800-850{ }^{\circ} \mathrm{C}$ and 1.7-1.9 $\mathrm{GPa}$ for Spačice eclogite, $1160-1180^{\circ} \mathrm{C}$ a $1.7-1.9 \mathrm{GPa}$ for the quartz-rich eclogite, and $960{ }^{\circ} \mathrm{C}$ a $1.9 \mathrm{GPa}$ for other eclogites. Faryad (2009) determined peak conditions of kyanite eclogite and associated felsic granulite from Spačice at 3.4 GPa and $900-960{ }^{\circ} \mathrm{C}$. Lower peak conditions were inferred for eclogite associated with serpentinite from Borek south of the contact between the Běstvina Unit and the adjacent Moldanubian Zone (650 ${ }^{\circ} \mathrm{C}$ and 1.4-1.5 GPa; Medaris et al. 1998).

Apparently, small bodies of eclogites, garnet peridotites and amphibolites frequently associate into the zones of strong deformation marked by mica schist and phyllonite belts. Mutual relationships of these rock zones incorporating UHP mantle peridotites and eclogites with the prevailing medium-grade metasediments, HP/HT rocks and migmatites are mostly rather unclear due to the thick Upper Cretaceous shallow-sea and Quaternary aeolian sedimentary cover. A small erosion window at the northern tip of the KHC revealed the occurrence of Cpxgranulite (sample 82 in Fig. 1), the only known exposure of this kind in KHC outside the Běstvina Unit.

4. The fourth poorly exposed northern segment of the KHC - the Plaňany Unit (Fišera 1977) - is extensively covered by the sediments of the Bohemian Cretaceous Basin. It crops out only in a dimension stone quarry and in a series of minor erosion windows north of Plaňany. The definition of this unit was based mainly on an unusual occurrence of Ti-rich amphibole-pyroxene migmatite enclosing a number of small peridotite and pyroxenite enclaves (Fišera 1981). Another indicative feature is the presence of a metasedimentary sequence containing calc-silicate rocks, and distinct type of massive nebulitic migmatites, both overprinted by strong localized shearing accompanied by late sillimanite crystallization. This poorly exposed northernmost segment of the KHC may indicate an inversely zoned metamorphic pattern, or a 
higher tempered thrust slice possibly corresponding to the Monotonous Unit of the MZ.

The Moldanubian Zone adjacent to the south-western and southern margin of the KHC is formed of the Varied Unit that extends in an arcuate belt between Český Šternberk and Čáslav. Further to SE, the Moldanubian margin is partially covered by the Quaternary sediments and the area was usually ascribed to the Monotonous Unit; however, its regional setting is ambiguous. This ambiguity was expressed, for instance, by a proposal of "Transitional Zone" between the Moldanubian Zone and KHC by Mísař in Ondř́k et al. (1996). Behind the Prribyslav Mylonite Zone, the Moldanubian Monotonous Unit borders on the Strážek part of the MZ. Some Moldanubian lithological members, such as felsic Ky-Grt orthogneiss, garnetiferous orthogneisses, eclogites, pyroxenites and garnet peridotites, though indicating similar sources, exhibit somewhat different tectonometamorphic history from those documented from the KHC rock assemblage (Štědrá in Pertoldová et al. 2007).

\section{Geological position of HP metabasic bodies}

\subsection{Metabasites in the $\mathrm{KHC}$}

High-grade metabasic rocks of the KHC and neighbouring $\mathrm{MZ}$ include eclogites, garnet pyroxenites and pyroxene granulites from already known and newly found localities, disseminated mostly in the inner part of the $\mathrm{KHC}$ and in the Malín and Běstvina units along the KHC margin. These eclogites form minor ellipsoidal boudins with amphibolized mantle and strongly sheared outer host rocks and are accompanied in places by completely recrystallized amphibolites. Occurrences of elongated bodies of low- to medium-grade metabasites, on the other hand, are scattered along the outer Mica Schist Zone in the Kutná Hora Complex and in the Varied Unit along the north-eastern margin of the Moldanubian Zone. Garnet $( \pm \mathrm{Cpx})$ amphibolites and amphibolites with HP relicts form a large body outcropping near Mančice, Polní Voděrady, and Lošany southwest of Kolín (see Kratochvíl 1952; Novák and Vrbová 1994). Several occurrences of amphibolized metabasites beyond the scope of this paper were also found near the E margin of the KHC north (Fišera 1977) and southeast of Kouřim.

The KHC eclogites underwent various degrees of postHP metamorphic stages including allochemical retrograde changes (amphibolization, chloritization and biotitization). In spite of their limited size, the boudins still provide us with well-preserved HP mineral assemblage.

Generally, most of the occurrences of eclogites were found in the inner KHC zone. They are frequently spatial- ly associated with garnet peridotites, either loosely bound (e.g., locations at Bohouňovice, Roztěž, Doubravčany, Chotouchov, Poličany, Vrbův Mlýn, Kutná Hora, Úhrov, Spačice-Doubrava), or as layers directly incorporated in the peridotite bodies like garnet pyroxenites from Bečváry (Paděra 1972; Beard et al. 1992; Medaris et al. 1995a) and the UHP mantle-derived sequence from Spačice in the Běstvina Unit (Faryad 2009). Some local occurrences of peridotite-related eclogites and granulites were studied in detail by Medaris and his co-workers, who included isotope data (1995a, 1995b, 1998 and 2006). The present study deals only with the metabasites loosely related to peridotite lenses.

In the north, the Plaňany Unit yields rare garnet peridotites and MP garnetites in nodules enclosed in migmatitic host rocks but true HP rocks have not been found so far. There are also occurrences of HP rocks along the northern boundary of the KHC (adjacent to the buried western continuation of the Železné Hory Fault Zone), exposed by scarce erosion windows, e.g., near Miškovice by Plaňany, Tři Dvory east of Kolín, and Týnec nad Labem. The structural settings of these bodies as well as recognition of the main regional boundaries delineating the individual basement units (KHC vs. Moldanubian and Teplá-Barrandian zones) are uncertain because of the platform cover. However, petrological features indicate similar provenance and metamorphic path of these rocks, namely to the high-grade rocks in the KHC. The basic typology of occurrences of the studied HP rocks is included in the Tab. 1.

\subsection{Eclogites in the NE margin of the Moldanubian Zone}

High-pressure metabasites associated with garnet peridotites were also found in course of the geological mapping campaign in 2003-2005 in the Moldanubian Zone southeast of Chotěboř, in the triple junction between the Strážek Unit, the Central Bohemian MZ, and the southeastern tip of the Moldanubian Varied Unit. All these samples used for comparison are from locations west of the Přibyslav Fault Zone.

\section{Methods and sample selection}

The studied eclogites mostly represent the KHC Inner Zone (Bořetice, Poličany, Roztě̌̌), and a few are from locations scattered along the northern margin of the KHC and the Běstvina Unit (Miškovice, Tři Dvory, Spačice-Doubrava and Úhrov).

As new rock samples from the above-mentioned Chotěbor part of the Moldanubian Zone were available from ongoing geological mapping, the reference sample 
Tab. 1 List of studied samples, their location and mineral assemblages

\begin{tabular}{|c|c|c|c|c|c|c|c|c|c|}
\hline Sample & Locality & Unit & Rock type & $\begin{array}{l}\text { Loc. } \\
\text { type }\end{array}$ & $\begin{array}{c}\text { Peak mineral } \\
\text { assemblage }\end{array}$ & $\begin{array}{c}\text { Omp/sympl. } \\
\text { (vol. \%)* }\end{array}$ & Rock assemblage & X-coordinate & Y-coordinate \\
\hline KMV44 & Poličany & KHC & eclogite & quarry & $\begin{array}{c}\text { Grt-Omp- } \\
\text { Qtz-Hbl-Rt }\end{array}$ & $5 / 95$ & $\begin{array}{l}\text { felsic gneiss, } \\
\text { migmatite, mica } \\
\text { schist, garnet } \\
\text { amphibolite }\end{array}$ & $49^{\circ} 56^{\prime} 01.45^{\prime \prime} \mathrm{N}$ & $15^{\circ} 15^{\prime} 39.46^{\prime \prime} \mathrm{E}$ \\
\hline KMV66 & Bořetice & $\mathrm{KHC}$ & eclogite & outcrop & $\begin{array}{c}\text { Grt-Omp-Rt- } \\
\text { Qtz }\end{array}$ & $25 / 75$ & $\begin{array}{l}\text { mica schists, } \\
\text { gneisses }\end{array}$ & $49^{\circ} 59^{\prime} 08.34^{\prime \prime} \mathrm{N}$ & $15^{\circ} 11^{\prime} 12.31 " \mathrm{E}$ \\
\hline KMV95 & Bořetice & $\mathrm{KHC}$ & $\begin{array}{l}\text { Ky eclogite, } \\
\text { mylonitized }\end{array}$ & blocks & $\begin{array}{c}\text { Grt-Omp-Rt- } \\
\text { Ky-Qtz }\end{array}$ & $85 / 15$ & $\begin{array}{l}\text { garnet peridotite, } \\
\text { gneiss }\end{array}$ & $49^{\circ} 58^{\prime} 20.65^{\prime \prime} \mathrm{N}$ & $15^{\circ} 10^{\prime} 06.86^{\prime \prime} \mathrm{E}$ \\
\hline KMV118 & Roztěž & $\mathrm{KHC}$ & eclogite & blocks & $\begin{array}{l}\text { Grt-Omp- } \\
\text { Qtz-Rt }\end{array}$ & $90 / 10$ & $\begin{array}{l}\text { migmatized } \\
\text { paragneiss, } \\
\text { mica schist, } \\
\text { Grt peridotite }\end{array}$ & $49^{\circ} 54^{\prime} 41.33^{\prime \prime} \mathrm{N}$ & $15^{\circ} 11^{\prime} 59.41 " \mathrm{E}$ \\
\hline KMV82 & Miškovice & $\mathrm{KHC}$ & Cpx granulite & outcrop & $\begin{array}{c}\text { Grt-Omp-Rt- } \\
\text { Pl-Bt }\end{array}$ & $?$ & $\begin{array}{l}\text { Grt-Bt gneiss, } \\
\text { felsic Qtz granulite }\end{array}$ & $50^{\circ} 01^{\prime} 54.01 " \mathrm{~N}$ & $14^{\circ} 59^{\prime} 35.07^{\prime \prime} \mathrm{E}$ \\
\hline KMV76 & Tři Dvory & $\mathrm{KHC}$ & $\begin{array}{l}\text { eclogitized } \\
\text { metagabbro }\end{array}$ & outcrop & $\begin{array}{c}\text { Grt-Omp-Rt- } \\
\text { MgOpx-Hbl- } \\
\text { Zo-Ky-Pl }\end{array}$ & $5 / 95$ & gabbro-amphibolite & $50^{\circ} 02^{\prime} 03.28^{\prime \prime} \mathrm{N}$ & $15^{\circ} 14^{\prime} 58.49^{\prime \prime} \mathrm{E}$ \\
\hline KMV116 & Doubravčany & $\mathrm{KHC}$ & $\begin{array}{c}\text { Cpx-Grt } \\
\text { amphibolite }\end{array}$ & outcrop & $\begin{array}{l}\text { Grt-Amp- } \\
\text { Qtz-Cpx }\end{array}$ & (Cpx) & $\begin{array}{l}\text { migmatite, } \\
\text { orthogneiss }\end{array}$ & $49^{\circ} 57^{\prime} 32.98^{\prime \prime} \mathrm{N}$ & $15^{\circ} 00^{\prime} 01.86^{\prime \prime} \mathrm{E}$ \\
\hline KMV30b & Úhrov & KHC-BU & eclogite & quarry & $\begin{array}{l}\text { Grt-Omp- } \\
\text { Qtz-Rt }\end{array}$ & $90 / 10$ & $\begin{array}{l}\text { garnet peridotite, } \\
\text { granulite, gneiss }\end{array}$ & $49^{\circ} 48^{\prime} 55.58^{\prime \prime} \mathrm{N}$ & $15^{\circ} 34^{\prime} 48.52^{\prime \prime} \mathrm{E}$ \\
\hline KMV103 & Spačice-Doubrava & KHC-BU & Ky eclogite & outcrop & $\begin{array}{c}\text { Grt-Omp-Rt- } \\
\text { Ky-Qtz }\end{array}$ & $15 / 85$ & $\begin{array}{l}\text { granulite, gneiss, } \\
\text { migmatite }\end{array}$ & $49^{\circ} 48^{\prime} 46.29^{\prime \prime} \mathrm{N}$ & $15^{\circ} 35^{\prime} 57.26^{\prime \prime} \mathrm{E}$ \\
\hline KMV96 & Bída & $\mathrm{MZ}$ & eclogite & blocks & $\begin{array}{c}\text { Grt-Omp-Rt- } \\
\text { Amp }\end{array}$ & $5 / 95$ & $\begin{array}{l}\text { refoliated } \\
\text { migmatite }\end{array}$ & $49^{\circ} 39^{\prime} 59.80^{\prime \prime} \mathrm{N}$ & $15^{\circ} 42^{\prime} 46.46^{\prime \prime} \mathrm{E}$ \\
\hline KMV109 & Borovský Creek & MZ & Ky eclogite & outcrop & $\begin{array}{l}\text { Grt-Omp- } \\
\text { Rt-Ky }\end{array}$ & $10 / 90$ & $\begin{array}{l}\text { refoliated } \\
\text { migmatite, } \\
\text { mylonite, garnet } \\
\text { peridotite }\end{array}$ & $49^{\circ} 38^{\prime} 09.28^{\prime \prime N}$ & $15^{\circ} 45^{\prime} 35.36^{\prime \prime} \mathrm{E}$ \\
\hline KMV110 & Krátká Ves & $\mathrm{MZ}$ & eclogite & blocks & $\begin{array}{l}\text { Grt-Omp-Rt- } \\
\text { Opx-Bt-Amp }\end{array}$ & $20 / 80$ & $\begin{array}{l}\text { Ky-Grt gneiss, } \\
\text { refoliated } \\
\text { migmatite }\end{array}$ & $49^{\circ} 37^{\prime} 31.38^{\prime \prime} \mathrm{N}$ & $15^{\circ} 40^{\prime} 23.02^{\prime \prime} \mathrm{E}$ \\
\hline
\end{tabular}

*Estimation of the relict omphacite/secondary $\mathrm{Cpx}-\mathrm{Pl}$ symplectite volume

set also includes eclogites from this area (Borovský Creek, Bída, Krátká Ves).

Complete list of the samples studied is given in Tab. 1 and their locations within the KHC and the adjacent part of the Moldanubian Zone are depicted in Fig. 1. All the relevant data are given in Tabs 2-4.

The KHC samples were studied using field observations, structural relationships, microprobe qualitative determination, mineral composition data, whole-rock geochemical analyses, and the conventional exchange geothermobarometry combined with construction of the Thermocalc P-T pseudosection. The ratio of the major elements typical of basic rocks is shown in the binary plots and the AFM (Irvine and Baragar 1971) and Al$\mathrm{Mg}-\mathrm{Fe}+\mathrm{Ti}$ diagrams (Jensen 1976, Fig. 2) using the GCDkit package by Janoušek et al. (2006). Additional eclogite whole-rock analyses, also shown in Fig. 2, are taken from Štědrá et al. (2007) and come from the localities Spačice (Běstvina Unit), Vrbův mlýn, V Hutích and Chotouchov (inner KHC).
Newly obtained P-T data were compared with the information on the HP eclogite/granulite/peridotite assemblages from the KHC published previously (Medaris et al. 2005, 2006; Faryad 2009). The PX-NOM programme (Sturm 2002) was employed for the temperature estimates using the garnet-pyroxene equilibria, the GPT spreadsheet (Reche and Martinez 1996) for the orthopyroxene-garnet pair, and the geothermobarometer for the Grt-Cpx-Ky-Qtz/Co eclogites (Ravna and Terry 2004) were used for suitable rocks.

Pseudosection modelling was undertaken using THERMOCALC 3.31 (Powell et al. 1998, recent upgrade) and the internally consistent thermodynamic dataset 5.5 (Holland and Powell 1998, November 2003 upgrade) in the $\mathrm{Na}_{2} \mathrm{O}-\mathrm{CaO}-\mathrm{FeO}-\mathrm{MgO}-\mathrm{Al}_{2} \mathrm{O}_{3}-\mathrm{SiO}_{2}-\mathrm{H}_{2} \mathrm{O}-\mathrm{TiO}_{2}-\mathrm{O}$ (NCFMASHTO) system for basic rocks. Some parts of the pseudosection may be metastable with respect to meltbearing assemblages under high-T conditions, and thus the absence of an appropriate melt model for basic systems must be considered. In order to include fluid-bearing 

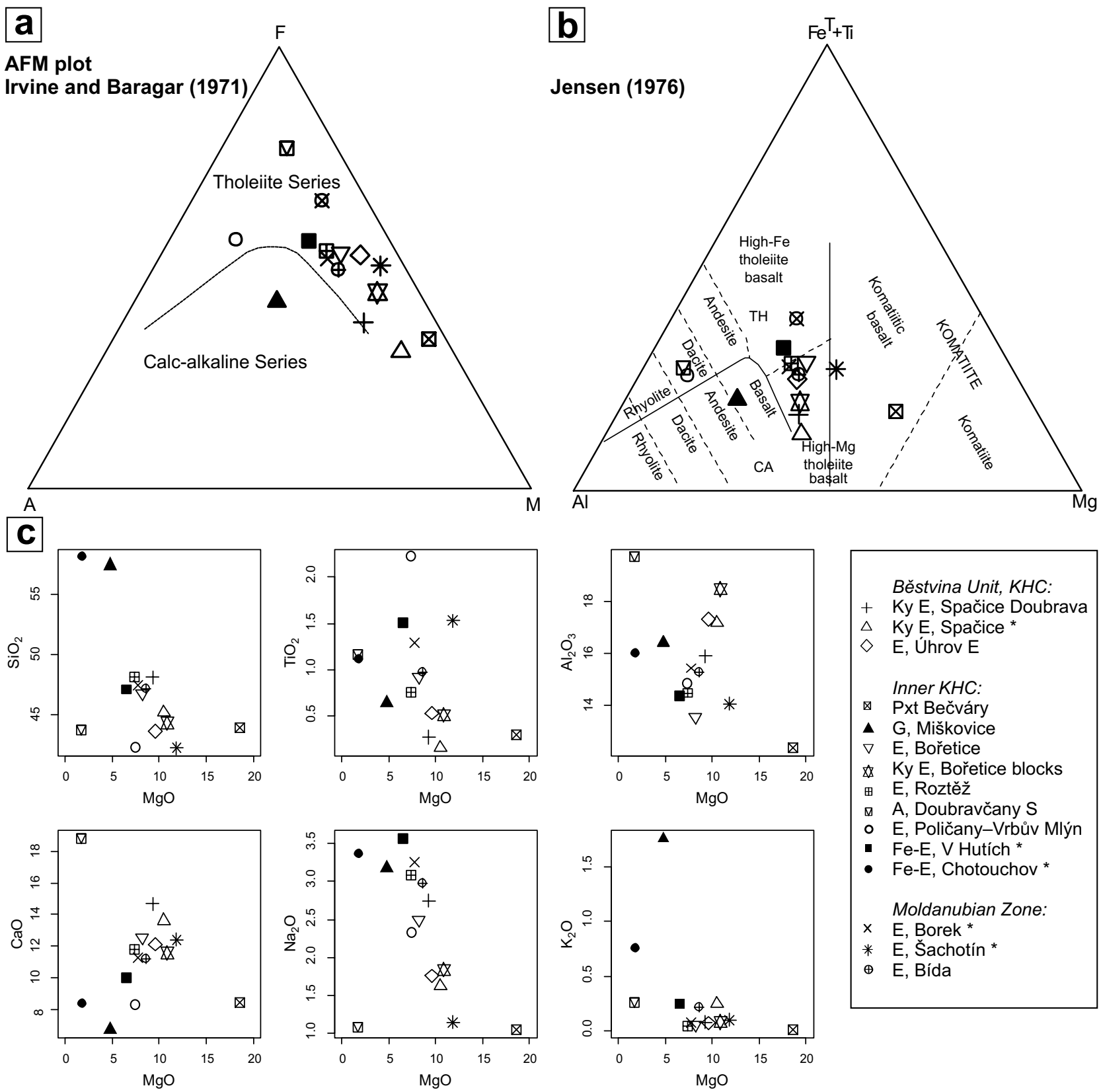

Běstvina Unit, KHC:

$+\quad$ Ky E, Spačice Doubrava

$\triangle$ Ky E, Spačice *

$\diamond E$, Úhrov $E$

Inner KHC:

$\bowtie \quad$ Pxt Bečváry

- G, Miškovice

$\nabla \quad$ E, Bořetice

Ky E, Bořetice blocks

田 E, Roztěž

¿ A, Doubravčany $S$

- E, Poličany-Vrbův Mlýn

- Fe-E, V Hutích *

- Fe-E, Chotouchov *

Moldanubian Zone:

$x$ E, Borek *

* E, Šachotín *

$\oplus$ E, Bída
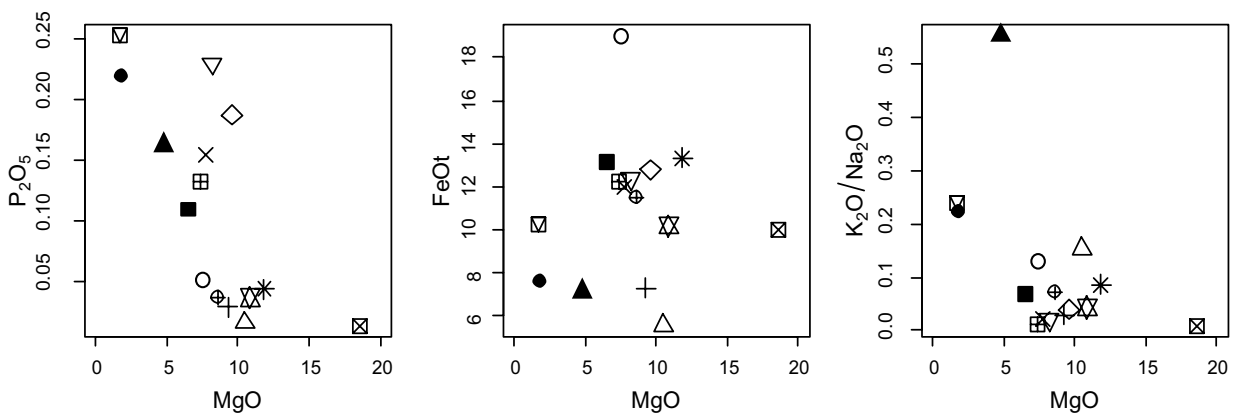

Fig. 2 Whole-rock chemical composition of the high-pressure metabasic rocks from the Kutná Hora Complex and the adjacent part of the Moldanubian Zone: a - AFM plot after Irvine and Baragar (1971) (A: $\mathrm{Na}_{2} \mathrm{O}+\mathrm{K}_{2} \mathrm{O}, \mathrm{F}: \mathrm{FeOt}, \mathrm{M}: \mathrm{MgO}$ ) showing tholeiitic composition of the studied eclogites and amphibolites; $\mathbf{b}$ - Compositional variations of metabasites in the multicationic plot of Jensen (1976) for volcanic rocks; $\mathbf{c}-$ Binary plots of $\mathrm{MgO}$ vs. major- and minor-element oxides.

* complementary data from Štědrá et al. (2007). Abbreviations of rock types in the legend: A - amphibolite, E - eclogite, G - granulite, Pxt - pyroxenite. 
Tab. 2 Whole-rock major-element compositions of the KHC metabasites (wt. \%)

\begin{tabular}{|c|c|c|c|c|c|c|c|c|c|c|c|c|}
\hline $\begin{array}{l}\text { Sample } \\
\text { Locality }\end{array}$ & $\begin{array}{l}\text { KMV66 } \\
\text { Bořetice } \\
\text { outcrop }\end{array}$ & $\begin{array}{c}\text { KMV95f } \\
\text { Bořetice } \\
\text { blocks }\end{array}$ & KMV118 & $\begin{array}{c}\text { KH53b } \\
\text { Vrbův } \\
\text { Mlýn }\end{array}$ & $\begin{array}{c}\text { KK85 } \\
\text { Doubravčany }\end{array}$ & $\begin{array}{l}\text { KMV 82b } \\
\text { Miškovice }\end{array}$ & $\begin{array}{l}\text { KMV5 } \\
\text { Bečváry }\end{array}$ & $\begin{array}{c}\text { KMV116 } \\
\text { Chotouchov }\end{array}$ & $\begin{array}{c}\text { KMV103 } \\
\text { Spačice } \\
\text { Doubrava }\end{array}$ & $\begin{array}{c}\text { KMV30b } \\
\text { Úhrov }\end{array}$ & $\begin{array}{c}\text { KMV26 } \\
\text { Borek u } \\
\text { Chotěboře }\end{array}$ & $\begin{array}{c}\text { KMV96 } \\
\text { Bída }\end{array}$ \\
\hline $\begin{array}{c}\text { Petrology }^{* * k *} \\
\text { Unit }^{* k \cdot k \cdot k}\end{array}$ & $\begin{array}{c}\mathbf{E} \\
\text { KHC }\end{array}$ & $\begin{array}{l}\text { Ky E } \\
\text { KHC }\end{array}$ & $\begin{array}{c}\mathrm{E} \\
\text { KHC }\end{array}$ & $\begin{array}{c}\mathrm{E} \\
\text { KHC }\end{array}$ & $\begin{array}{r}\text { Fe A } \\
\text { KHC }\end{array}$ & $\begin{array}{c}\text { Cpx G } \\
\text { KHC }\end{array}$ & $\begin{array}{c}\text { Grt Pxt } \\
\text { KHC }\end{array}$ & $\begin{array}{l}\text { Fe E } \\
\text { KHC }\end{array}$ & $\begin{array}{c}\text { Ky E } \\
\text { KHC BU }\end{array}$ & $\begin{array}{c}\mathrm{E} \\
\text { KHC BU }\end{array}$ & $\begin{array}{c}\mathbf{E} \\
\mathbf{M Z}\end{array}$ & $\begin{array}{c}\mathbf{E} \\
\mathbf{M Z}\end{array}$ \\
\hline $\mathrm{SiO}_{2}$ & 46.72 & 44.26 & 48.12 & 42.14 & 43.70 & 57.46 & 43.90 & 58.21 & 48.07 & 43.56 & 47.41 & 47.16 \\
\hline $\mathrm{TiO}_{2}$ & 0.92 & 0.51 & 0.75 & 2.22 & 1.16 & 0.64 & 0.30 & 1.11 & 0.27 & 0.53 & 1.29 & 0.97 \\
\hline $\mathrm{Al}_{2} \mathrm{O}_{3}$ & 13.56 & 18.46 & 14.48 & 14.82 & 19.70 & 16.42 & 12.36 & 15.99 & 15.89 & 17.31 & 15.43 & 15.25 \\
\hline $\mathrm{Fe}_{2} \mathrm{O}_{3}$ & 1.59 & 1.40 & 13.62 & 21.12 & 11.40 & 1.42 & 2.31 & 0.95 & 2.00 & 1.95 & 2.96 & 2.24 \\
\hline $\mathrm{FeO}$ & 10.92 & 8.92 & - & - & - & 5.85 & 7.92 & 6.77 & 5.49 & 11.05 & 9.32 & 9.51 \\
\hline $\mathrm{MgO}$ & 8.20 & 10.85 & 7.36 & 7.53 & 1.73 & 4.78 & 18.58 & 1.77 & 9.28 & 9.59 & 7.73 & 8.61 \\
\hline $\mathrm{MnO}$ & 0.31 & 0.15 & 0.23 & 0.36 & 0.25 & 0.11 & 0.24 & 0.16 & 0.16 & 0.28 & 0.24 & 0.22 \\
\hline $\mathrm{CaO}$ & 12.55 & 11.57 & 11.79 & 8.27 & 18.84 & 6.70 & 8.45 & 8.33 & 14.67 & 12.11 & 11.26 & 11.19 \\
\hline $\mathrm{Li}_{2} \mathrm{O}$ & n.d. ${ }^{*}$ & 0.01 & 0.01 & n.d. & n.d. & 0.01 & n.d. & n.d. & n.d. & n.d. & n.d. & n.d. \\
\hline $\mathrm{Na}_{2} \mathrm{O}$ & 2.50 & 1.84 & 3.09 & 2.33 & 1.08 & 3.18 & 1.05 & 3.36 & 2.75 & 1.76 & 3.26 & 2.98 \\
\hline $\mathrm{K}_{2} \mathrm{O}$ & 0.05 & 0.08 & 0.04 & 0.29 & 0.26 & 1.76 & 0.01 & 0.75 & 0.08 & 0.07 & 0.07 & 0.21 \\
\hline $\mathrm{P}_{2} \mathrm{O}_{5}$ & 0.23 & 0.04 & 0.13 & 0.05 & 0.25 & 0.16 & 0.01 & 0.22 & 0.03 & 0.19 & 0.15 & 0.04 \\
\hline $\mathrm{F}$ & 0.005 & 0.032 & n.d. & n.d. & n.d. & 0.077 & 0.002 & 0.004 & 0.013 & 0.014 & 0.003 & 0.005 \\
\hline LOI & 1.00 & $1.43^{* * *}$ & 0.49 & 0.07 & 0.56 & 1.33 & 4.14 & 2.18 & 0.70 & 0.57 & 0.66 & 1.39 \\
\hline $\mathrm{H}_{2} \mathrm{O}^{-}$ & 0.12 & 0.13 & 0.17 & 0.10 & 0.10 & 0.14 & 0.66 & 0.11 & 0.10 & 0.07 & 0.11 & 0.21 \\
\hline Total & 98.67 & 98.25 & 100.28 & 99.30 & 99.03 & 100.04 & 99.93 & 99.90 & 99.50 & 99.05 & 99.90 & 99.99 \\
\hline
\end{tabular}

"n.d. = not detected; ${ }^{* *} \mathrm{H}_{2} \mathrm{O}^{+} ;{ }^{* * *} \mathrm{E}=$ eclogite, $\mathrm{Ky} \mathrm{E}=$ kyanite eclogite, $\mathrm{Fe} \mathrm{A}=\mathrm{Fe}$ amphibolite, $\mathrm{Cpx} \mathrm{G}=$ clinopyroxene granulite, Grt Pxt $=$ garnet pyroxenite, $\mathrm{Fe} \mathrm{E}=$ Fe eclogite; ${ }^{* * *} \mathrm{KHC}=$ Kutná Hora Complex, $\mathrm{KHC} \mathrm{BU}=$ Běstvina Unit, $\mathrm{MZ}=$ Moldanubian Zone

HP/MP minerals (i.e. amphibole) observed under a microscope, an estimated amount of $1 \mathrm{wt} \%$ of $\mathrm{H}_{2} \mathrm{O}(3.43$ mol. \%) was added to the system. A recent clinopyroxene model based on the study of Green et al. (2007), plagioclase model of Holland and Powell (2003), amphibole model of Diener et al. (2007), garnet model of White et al. (2007), epidote model of Holland and Powell (1998), chlorite model of Holland et al. (1998), magnetite model of White et al. (2002) as well as ilmenite with hematite model of White et al. (2000) were all invoked to calculate the pseudosection for the eclogite from Roztěž.

\section{Petrology of eclogites}

\subsection{Description of the studied samples}

\subsubsection{KMV44 Poličany}

The eclogite was sampled in an old quarry north-west of the village of Poličany. A boudin reaching some $200 \mathrm{~m}$ in length is the largest of all the eclogite bodies studied. The country rocks include felsic gneisses, garnet- and kyanitebearing mica schists, amphibolites and migmatites. The whole-rock basaltic composition of the sample from the Vrbův Mlýn quarry nearby accounts for relative enrichment of eclogite in $\mathrm{FeO}$ and $\mathrm{TiO}_{2}$, as well as low $\mathrm{CaO}$ within the studied set (Fig. 2, Tab. 2). The HP mineral assemblage consists of garnet, omphacite, high-pressure amphibole, quartz, and accessories rutile, ilmenite, zircon and apatite (Fig. 3a). Compositionally zoned garnet (two grains: older stage $\mathrm{Alm}_{43-62}, \operatorname{Prp}_{8-23}, \mathrm{Grs}_{12-30}$ and $\mathrm{Sps}_{2-6}$ mol. \%, and younger stage: $\mathrm{Alm}_{43-49}, \operatorname{Prp}_{20-25}, \mathrm{Grs}_{22-27}$ and $\mathrm{Sps}_{1}$ mol. \%) forms large rotated porphyroblasts with pre-eclogite stage inclusions in the core of the first grain (Bt, Amp), and later HP mineral inclusions (Omp, $\mathrm{Rt}$ ) close to the outer rim. Omphacite was extensively replaced by Pl-CpxII symplectite and was amphibolized subsequently. Samples from Poličany-Vrbův Mlýn and V Hutích shown in Fig. 2 are spatially closely related to the Poličany eclogite, within $1 \mathrm{~km}$ distance.

\subsubsection{KMV66 Bořetice NE}

A several-metres-long elongated eclogite boudin is exposed at the bottom of the Polepka Creek valley north of Bořetice, $80 \mathrm{~m}$ west of the railway bridge. The host rocks are felsic migmatites and mica schists; a quarried body of garnet peridotite is located within a distance of $400 \mathrm{~m}$. The whole-rock composition of eclogite corresponds to tholeiitic protolith with low $\mathrm{Al}_{2} \mathrm{O}_{3}$ and $\mathrm{K}_{2} \mathrm{O}$ and high $\mathrm{Cr}_{2} \mathrm{O}_{3}, \mathrm{NiO}$ and $\mathrm{P}_{2} \mathrm{O}_{5}$ components. The eclogite is banded, with alternating HP amphibole- $\left(\mathrm{Na}_{2} \mathrm{O}\right.$ in amphibole up to $4.5 \mathrm{wt}$ \%) and omphacite-dominated layers, both 

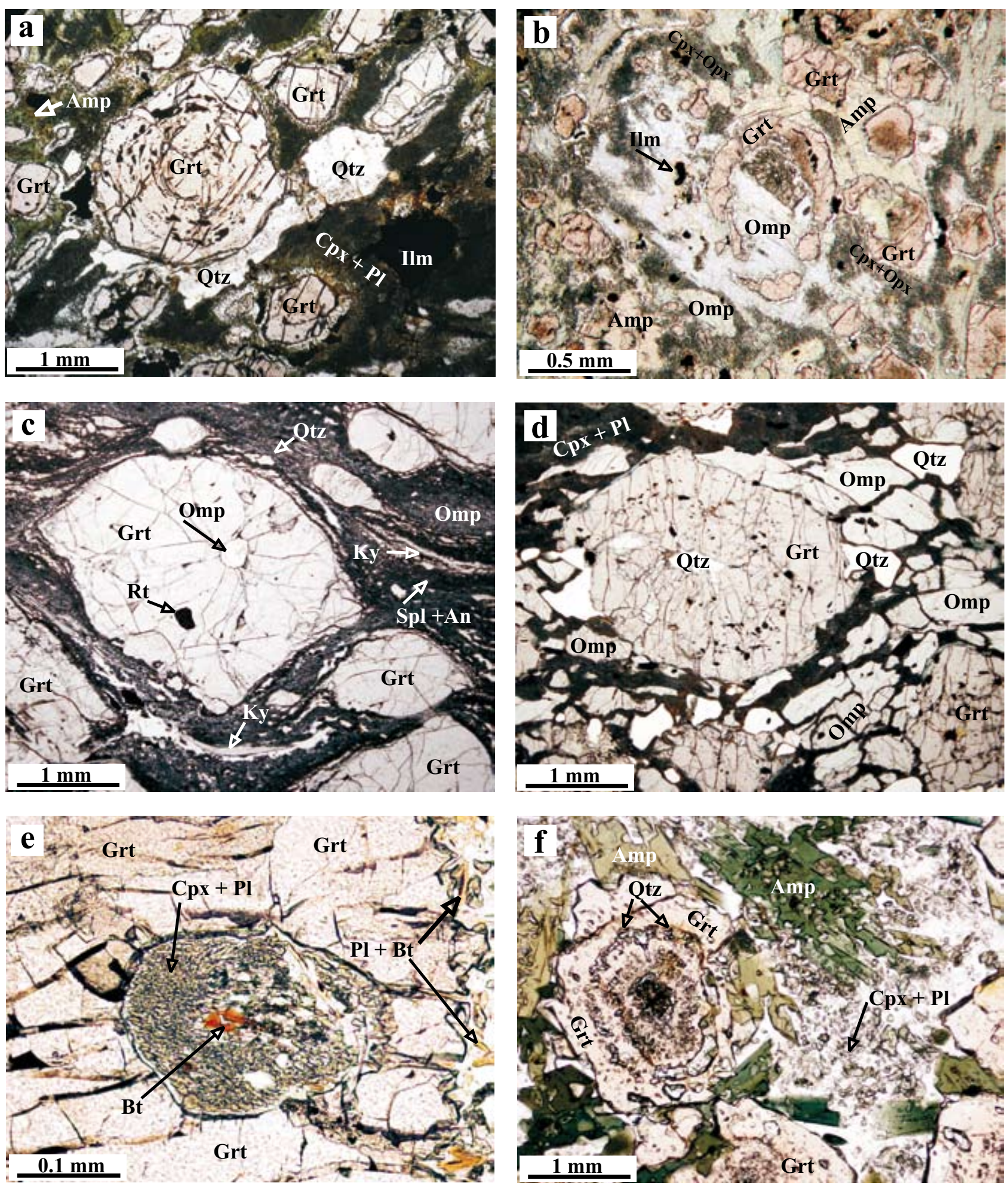

Fig. 3 Photomicrographs of high-pressure metabasites from the inner part of the Kutná Hora Complex (plane polarized light). a - Retrogressed eclogite KMV44 from Poličany with inclusions of pre-HP minerals in garnet; $\mathbf{b}$ - Eclogitized metagabbro KMV76 from Tři Dvory with skeletal garnet and well preserved matrix Na-Cpx (Omp); c - Strongly mylonitized Ky-eclogite KMV95d from Bořetice showing matrix composed of fine-grained omphacite, elongated grains of kyanite, and recrystallized chains of Grt II; d - Eclogite KMV118 from Roztěž with zoned garnet poikiloblasts with Qtz inclusions and preserved matrix omphacite in places transformed to dark symplectite; $\mathbf{e}$ - Clinopyroxene granulite KMV82 from Miškovice - a detail of the Na-clinopyroxene, biotite and plagioclase aggregate after omphacite enclosed in garnet. Garnet rim is corroded and replaced by multiphase reaction corona including plagioclase, biotite, and clinopyroxene; f - Pyroxene-bearing Fe-rich amphibolite KMV116 from Doubravčany displays aggregate distribution of $\mathrm{Cpx}$ droplets in plagioclase. 

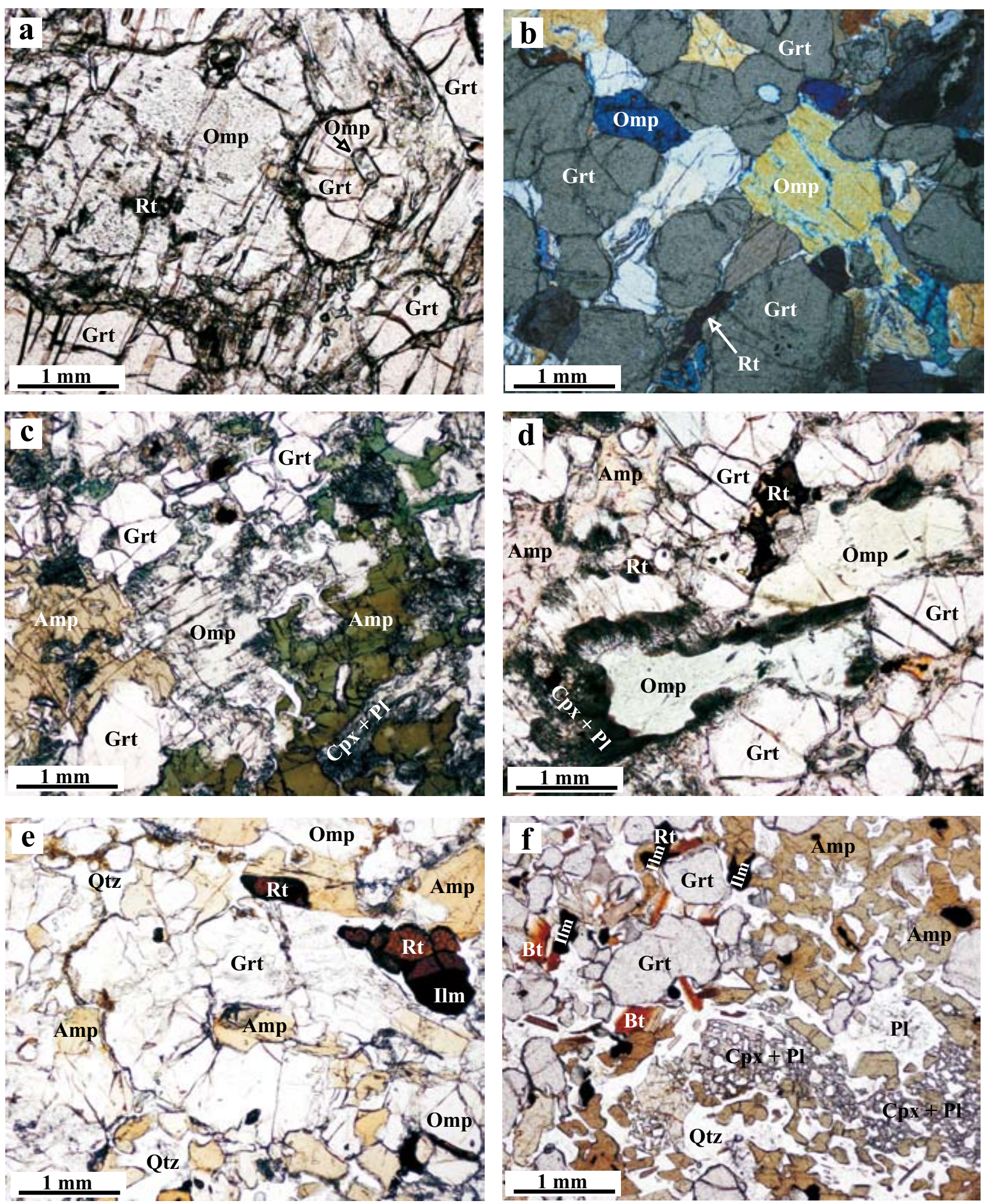

Fig. 4 Photomicrographs of HP metabasites from the Běstvina Unit (eastern KHC, a-b) and the adjacent part of the Moldanubian Zone (c-f). Plane polarized light if not stated otherwise. a - Well preserved eclogite KMV30b from Úhrov with lamellar Ab exsolutions in the matrix omphacite; b - Fresh eclogite KMV103d from Spačice-Doubrava showing equilibrium garnet (in grey), dominant matrix omphacite, and an initial exsolution of albite from the latter (crossed nicols); $\mathbf{c}$ - Partially amphibolized eclogite KMV96 from Bída with relict of pale green omphacite; d - Eclogite KMV109b from the Borovský Creek; e - Ti-rich amphibole- and biotite-bearing HP granulite KMV110b from Krátká Ves; f - Ti-rich high-pressure Grt-Cpx-Hbl-Bt-Qtz-Rt-Ilm rock from Oudoleň with relict plagioclase (right centre), and a poikilitic aggregate of CpxII (lower right). 
of which are rich in garnet $\left(\mathrm{Alm}_{50-55}, \operatorname{Prp}_{16-18}, \mathrm{Grs}_{24-32}\right.$, $\left.\mathrm{Sps}_{1-2}\right)$, ilmenite and rutile. Peak relict omphacite is highly sodic $\left(\max . \mathrm{X}_{\mathrm{Jd}}=38.5 \mathrm{~mol} . \%\right.$ for $6.2 \mathrm{wt} . \% \mathrm{Na}_{2} \mathrm{O}$ ) and reaches $\mathrm{Na}_{2} \mathrm{O}$ contents as high as $6.7 \mathrm{wt} . \%$ in relict cores. The sodium content decreases through medium $\mathrm{X}_{\mathrm{Jd}}$ $=15$ to minimum $\mathrm{X}_{\mathrm{Jd}}=2 \mathrm{~mol} . \%$ in the very late globular Cpx grains. The intensity of hydration increases along fractures and towards the mantle of the eclogite boudin, bearing newly crystallized poikiloblastic low-Na amphibole, epidote, clinozoisite, plagioclase and titanite.

\subsubsection{KMV95 Bořetice}

Small blocks of strongly deformed coarse-grained Kybearing eclogite (Grt-Omp-Qtz-Ky-Rt) were found in direct contact with garnet peridotite, just above the "excursion" quarry in the deformed peridotite north of Borretice. As the eclogite is found in loose blocks, it is not possible to determine whether it occurs inside or along the outer margin of the peridotite lens. The medium-grained rock with light matrix around garnet is strongly deformed to "augen" eclogite (Fig. 3c), which seems to be an analogue of the deformational fabrics in the peridotite boudin with linear structures in the quarry. Garnet, quartz and kyanite grains are strongly sheared and recrystallized into curved ribbons between floating grains of augen-like garnet porphyroclasts. Two analysed garnet grains display different compositions, the second with high pyrope content (a smaller grain: Alm $_{33-42}$ $\operatorname{Prp}_{30-26}$ Grs $_{31-27} \mathrm{Sps}_{\leq 1}$, the second, bigger grain preserves Fe-Mn rich core and differs also in rim compositions: $\mathrm{Alm}_{48-30} \operatorname{Prp}_{34-44} \mathrm{Grs}_{09-25} \mathrm{Sps}_{2-0.5}$, Fig. 5c).

In some samples, the total amount of kyanite increases up to 10 vol. $\%$ and corresponds to high whole-rock $\mathrm{Al}_{2} \mathrm{O}_{3}$ (18.5 wt. \%). Kyanite grains enclosed in garnet are generally almost euhedral and undeformed, except for twinning and undulatory extinction, in contrast to matrix kyanite grains where plastic elongation reaches an aspect ratio of c. $1: 20$. Deformation must have taken place under still very high $\mathrm{P}-\mathrm{T}$ conditions taking into account the recrystallization of euhedral fine-grained garnet chains in pressure shadows, and relative stability of omphacite. The latter mineral is very fine-grained due to mylonitization, forms $90-60 \%$ of the matrix, but subgrains are fresh and well preserved. The highest $\mathrm{Na}$ content in the matrix omphacite grains was detected in several samples (7-8 \%, max. 8.04 wt. $\left.\% \mathrm{Na}_{2} \mathrm{O}, \mathrm{X}_{\mathrm{Jd}}=55 \mathrm{~mol} . \%\right)$. It is slightly higher than that of Omp inclusion locked in garnet (7.3 wt. $\% \mathrm{Na}_{2} \mathrm{O}, \mathrm{X}_{\mathrm{Jd}} 50$ mol. \%, Fig. 6). Though the mineral composition indicates a lack of hydrated phases, rare nucleation of fine-grained high- $\mathrm{Na}$ amphibole was observed. The whole-rock chemical composition exhibits high $\mathrm{Al}_{2} \mathrm{O}_{3}, \mathrm{MgO}$ and $\mathrm{Cr}_{2} \mathrm{O}_{3}$ contents accompanied by depletion in $\mathrm{Zr}$ and $\mathrm{Y}$ of the tholeiitic basaltic protolith.
The unusual HP mineral assemblage and the metamorphic record of this eclogite are a subject of further detailed petrological study. A sample of kyanite eclogite described from Dobešovice and dated to $338 \mathrm{Ma}$ by the Sm-Nd method by Medaris et al. (1995a) could, in fact, be a similar rock type. The composition of the eclogite minerals is shown in Tabs 3 and 4.

\subsubsection{KMV76 Tři Dvory}

A resistant core of the previously quarried gabbro-amphibolite body remains exposed in the flat relief dominated by Quaternary and Cretaceous sediments at the NW limit of Tři Dvory. It is formed by layered eclogite, strongly affected by annealing, replacement by MP minerals and final retrogression. The presence of fine-grained granular Opx or $\mathrm{Cpx}-\mathrm{Hbl}$ aggregates in the centres of skeletal garnets indicates that the pre-eclogite protolith of the rock could have been two-pyroxene or olivine-bearing gabbro - possibly from the family of the Svatý Kříz Massif metabasites (Holub and Munschi 1984). Numerous relict grains constitute the Grt-Na-Cpx-Qtz-Ky-Zo-Rt $\mathrm{HP}$ assemblage. Garnet grains with inclusions of Rt, Ti and $\mathrm{Hbl}$ are either skeletal (Fig. 3b) or round, the latter exhibiting strong and complex zoning patterns with the Sps- and Grs-rich core and $\mathrm{Mg}$ increasing towards the rim $\left(\mathrm{Alm}_{47-56} \operatorname{Prp}_{6-27} \mathrm{Grs}_{15-34} \mathrm{Sps}_{0-12}\right)$. The Na-clinopyroxene (maximal $\mathrm{X}_{\mathrm{Jd}}=18.2, \mathrm{Na}_{2} \mathrm{O}=3.0$ wt. \%) was almost completely transformed into seriate lamellar symplectites, quartz preserving intergranular lobate forms, and prismatic kyanite and needle-shaped zoisite retrogressed to almost opaque spinel-bearing clusters of fine-grained secondary minerals. Amphibole in the matrix is secondary. The microstructure and mineral assemblage of the eclogite indicates a post-HP increase in temperature, which can be related to the final partial melting of the rock producing recrystallized coarse-grained amphibolite with Pl-rich melt pockets in the mantle of the boudin.

\subsubsection{KMV118 Roztěž}

A block of medium-grained eclogite was encountered in the middle of a newly constructed Roztěž golf course west of Malešov. The boudin was probably enclosed together with small bodies of garnet peridotites, skarns, and eclogites in highly sheared migmatitic biotite gneisses along a tectonic zone south of Kutná Hora (Štědrá ed. 2009). Its whole-rock composition indicates Qtz-rich tholeiitic protolith with slightly increased $\mathrm{FeO}, \mathrm{Na}_{2} \mathrm{O}$, $\mathrm{SiO}_{2}$, and low $\mathrm{K}_{2} \mathrm{O}$ (Fig. 2). The main matrix minerals are omphacite, garnet, rutile and quartz (Fig. 3d). Amphibole, plagioclase, clinopyroxene, epidote, ilmenite, zircon and Fe-sulphide are also present, in part as relict or secondary phases. Large garnet grains (up to $2 \mathrm{~mm}$ across) are 
Tab. 3 Garnet compositions from the studied eclogites (wt. \% and apfu recalculated to $12 \mathrm{O}$ equivalents)

\begin{tabular}{|c|c|c|c|c|c|c|c|c|c|c|c|c|c|c|c|}
\hline \multirow{4}{*}{$\begin{array}{c}\text { Unit* } \\
\text { Sample } \\
\text { Mineral } \\
\text { Position }\end{array}$} & \multicolumn{7}{|c|}{ inner part of $\mathrm{KHC}$} & \multicolumn{6}{|c|}{ KHC -- Běstvina Unit } & \multirow{3}{*}{\multicolumn{2}{|c|}{$\begin{array}{c}\text { MZ } \\
\text { KMV } 96 \text { Bída } \\
\text { Grt }\end{array}$}} \\
\hline & \multirow{2}{*}{\multicolumn{3}{|c|}{$\begin{array}{c}\text { KMV } 118 \text { Roztěž } \\
\text { Grt }\end{array}$}} & \multicolumn{4}{|c|}{ KMV 95d Bořetice } & \multirow{2}{*}{\multicolumn{3}{|c|}{$\begin{array}{c}\text { KMV 30b Úhrov } \\
\text { Grt }\end{array}$}} & \multirow{2}{*}{\multicolumn{3}{|c|}{$\begin{array}{c}\text { KMV 103d Spačice } \\
\text { Grt }\end{array}$}} & & \\
\hline & & & & \multicolumn{2}{|c|}{ Grt 1} & \multicolumn{2}{|c|}{ Grt 2} & & & & & & & & \\
\hline & core & inner part & outer rim & core & rim & core & rim & core & rim & diff. rim & core & rim & diff. rim & core & rim \\
\hline \multicolumn{16}{|l|}{ (wt. \%) } \\
\hline $\mathrm{SiO}_{2}$ & 38.01 & 38.22 & 38.50 & 39.01 & 39.18 & 38.72 & 40.79 & 39.27 & 39.57 & 39.99 & 39.23 & 39.27 & 38.98 & 38.73 & 39.56 \\
\hline $\mathrm{TiO}_{2}$ & 0.07 & 0.11 & 0.03 & 0.25 & 0.35 & 0.02 & 0.14 & 0.16 & 0.11 & 0.09 & 0.07 & 0.08 & 0.07 & 0.05 & 0.06 \\
\hline $\mathrm{Cr}_{2} \mathrm{O}_{3}$ & 0.02 & 0.02 & 0.00 & 0.02 & 0.03 & 0.03 & 0.06 & 0.02 & 0.03 & 0.04 & 0.01 & 0.07 & 0.05 & 0.03 & 0.00 \\
\hline $\mathrm{Al}_{2} \mathrm{O}_{3}$ & 21.46 & 21.18 & 21.59 & 21.85 & 21.57 & 21.89 & 22.07 & 21.87 & 22.04 & 21.96 & 22.39 & 21.91 & 21.51 & 21.84 & 22.20 \\
\hline $\mathrm{Fe}_{2} \mathrm{O}_{3}$ & 1.47 & 1.60 & 0.89 & 0.97 & 0.00 & 1.95 & 0.00 & 0.40 & 0.37 & 0.14 & 1.99 & 0.84 & 0.61 & 1.39 & 0.19 \\
\hline $\mathrm{FeO}$ & 20.07 & 20.82 & 23.72 & 17.75 & 20.44 & 23.77 & 15.26 & 18.11 & 18.14 & 19.78 & 18.55 & 19.70 & 23.49 & 22.35 & 22.24 \\
\hline $\mathrm{MnO}$ & 1.75 & 0.71 & & 0.47 & 0.47 & 0.99 & & & 0.41 & 0.42 & 0.53 & 0.53 & 0.69 & 0.64 & 0.65 \\
\hline $\mathrm{MgO}$ & 4.89 & 5.87 & 7.05 & 7.64 & 7.13 & 9.57 & 11.71 & 8.05 & 8.44 & 8.70 & 9.03 & 8.75 & 6.64 & 6.62 & 6.56 \\
\hline $\mathrm{CaO}$ & 11.60 & 10.70 & 7.19 & 11.40 & 10.26 & 3.50 & 9.40 & 11.07 & 10.67 & 9.51 & 9.15 & 8.57 & 8.02 & 9.03 & 9.97 \\
\hline $\mathrm{Na}_{2} \mathrm{O}$ & 0.02 & 0.02 & 0.00 & 0.08 & 0.03 & 0.00 & 0.08 & 0.01 & 0.03 & 0.00 & 0.02 & 0.05 & 0.09 & 0.00 & 0.00 \\
\hline Total & 99.37 & 99.27 & 99.50 & 99.45 & 99.46 & 100.44 & 99.83 & 99.34 & 99.82 & 100.63 & 100.96 & 99.75 & 100.14 & 100.68 & 101.43 \\
\hline \multicolumn{16}{|c|}{ apfu (per $12 \mathrm{O})$} \\
\hline $\mathrm{Si}$ & 2.966 & 2.975 & 2.986 & 2.980 & 3.012 & 2.957 & 3.031 & 2.996 & 3.000 & 3.014 & 2.949 & 2.990 & 3.006 & 2.969 & 2.999 \\
\hline $\mathrm{Ti}$ & 0.004 & 0.007 & 0.001 & 0.014 & 0.020 & 0.001 & 0.008 & 0.009 & 0.006 & 0.005 & 0.004 & 0.005 & & 0.003 & 0.003 \\
\hline $\mathrm{Cr}$ & 0.001 & 0.001 & 0.000 & 0.001 & 0.002 & 0.002 & 0.003 & 0.001 & 0.002 & 0.002 & 0.000 & 0.004 & 0.003 & 0.002 & 0.000 \\
\hline $\mathrm{Al}$ & 1.974 & 1.944 & 1.974 & 1.968 & 1.955 & 1.971 & 1.933 & 1.967 & 1.970 & 1.951 & 1.984 & 1.966 & 1.955 & 1.974 & 1.984 \\
\hline $\mathrm{Fe}^{3+}$ & 0.086 & 0.094 & 0.052 & 0.056 & 0.000 & 0.112 & 0.000 & 0.023 & 0.021 & 0.008 & 0.112 & 0.048 & 0.036 & 0.080 & 0.011 \\
\hline $\mathrm{Fe}^{2+}$ & 1.310 & 1.355 & 1.538 & 1.134 & 1.314 & 1.518 & 0.948 & 1.155 & 1.150 & 1.247 & 1.166 & 1.254 & 1.515 & 1.432 & 1.410 \\
\hline $\mathrm{Mn}$ & 0.116 & 0.047 & 0.035 & 0.031 & 0.031 & 0.064 & 0.020 & 0.025 & 0.026 & 0.027 & 0.033 & 0.034 & 0.045 & 0.042 & 0.042 \\
\hline $\mathrm{Mg}$ & 0.569 & 0.681 & 0.815 & 0.870 & 0.816 & 1.089 & 1.297 & 0.916 & 0.954 & 0.978 & 1.011 & 0.993 & 0.763 & 0.756 & 0.741 \\
\hline $\mathrm{Ca}$ & 0.970 & 0.893 & 0.597 & 0.933 & 0.845 & 0.286 & 0.748 & 0.905 & 0.867 & 0.768 & 0.737 & 0.699 & 0.662 & 0.742 & 0.810 \\
\hline $\mathrm{Na}$ & 0.003 & 0.003 & 0.000 & 0.012 & 0.004 & 0.000 & 0.011 & 0.002 & 0.005 & 0.000 & 0.002 & 0.007 & 0.013 & 0.000 & 0.000 \\
\hline \multicolumn{16}{|l|}{$(\mathrm{mol} . \%)$} \\
\hline Prp & 0.18 & 0.22 & 0.26 & 0.28 & 0.26 & 0.34 & 0.41 & 0.30 & 0.31 & 0.32 & 0.32 & 0.32 & 0.25 & 0.24 & 0.24 \\
\hline Alm & 0.42 & 0.43 & 0.50 & 0.36 & 0.42 & 0.48 & 0.30 & 0.38 & 0.38 & 0.40 & 0.37 & 0.41 & 0.49 & 0.46 & 0.47 \\
\hline Grs & 0.31 & 0.28 & 0.19 & 0.30 & 0.27 & 0.09 & 0.24 & 0.30 & 0.28 & 0.25 & 0.23 & 0.23 & 0.21 & 0.24 & 0.27 \\
\hline Sps & 0.04 & 0.01 & 0.01 & 0.01 & 0.01 & 0.02 & 0.01 & 0.01 & 0.01 & 0.01 & 0.01 & 0.01 & 0.01 & 0.01 & 0.01 \\
\hline $\mathrm{X}_{\mathrm{Fe}}\left(\mathrm{Fe}_{\mathrm{TOT}}\right)$ & 0.70 & 0.66 & 0.65 & 0.57 & 0.62 & 0.58 & 0.42 & 0.56 & 0.55 & 0.56 & 0.54 & 0.56 & 0.67 & 0.65 & 0.66 \\
\hline
\end{tabular}

* $\mathrm{KHC}=$ Kutná Hora Complex, $\mathrm{MZ}=$ Moldanubian Zone

occasionally rimmed by kelyphitic rims of plagioclase, amphibole and clinopyroxene, and contain several populations of inclusions. Plagioclase enclosed in the garnet core is almost pure albite, whereas plagioclase from garnet symplectite or in the matrix contains about 15 mol. \% of anorthite component. Omphacite grains are enclosed in the intermediate zone of garnet and in the matrix and display high $\mathrm{Na}$ content $\left(\mathrm{Na}_{2} \mathrm{O}=5.79\right.$ wt. $\%, \mathrm{X}_{\mathrm{Jd}}=$ 40 mol. \%, Fig. 6). Secondary clinopyroxene occurring in symplectite or in the matrix is predominantly Na-diopside $\left(\mathrm{X}_{\mathrm{Jd}} \sim 10 \mathrm{~mol} . \%\right)$ or diopside. Amphibole enclosed in the garnet core is ferroan pargasite, whereas poikiloblastic amphibole in the matrix is edenitic hornblende, and the amphibole forming the kelyphitic garnet rim is pargasite to pargasitic hornblende (Leake et al. 1997).
Zoned garnet ( $\mathrm{Alm}_{42-50} \operatorname{Prp}_{19-29} \mathrm{Grs}_{32-19} \mathrm{Sps}_{4-1}$ mol. \%) contains a $\mathrm{Ca}-\mathrm{Mn}$ rich core (Fig. 5a), which is rich in tiny inclusions of amphibole, albite and ilmenite (Fig. 5b). The intermediate zone of the grain encloses quartz and rarely epidote inclusions. A clearly expressed zone of rutile and ilmenite is located towards the rim and fine omphacite inclusions were also trapped in a vicinity of rutile. Inclusions of epidote, allanite and zoisite were found close to the rim of the grain and are possibly not primary. Garnet along the outer rim reacted with the (secondary?) fluid-bearing matrix minerals and was locally transformed to the amphibole-plagioclase kelyphite. Accessory zircon is common within the kelyphite. Numerous small inclusions of $\mathrm{Fe}-$, $\mathrm{Ni}$ - and $\mathrm{Cu}$-sulphides are present in the matrix. 
Tab. 4 Clinopyroxene compositions from the $\mathrm{KHC}$ eclogites (wt. \% and apfu recalculated to $6 \mathrm{O}$ equivalents)

\begin{tabular}{|c|c|c|c|c|c|c|c|c|c|c|}
\hline \multirow{3}{*}{$\begin{array}{c}\text { Unit* } \\
\text { Sample } \\
\text { Mineral } \\
\text { Position }\end{array}$} & \multicolumn{4}{|c|}{ inner part of $\mathrm{KHC}$} & \multicolumn{3}{|c|}{ KHC - Běstvina Unit } & \multirow{2}{*}{\multicolumn{3}{|c|}{$\begin{array}{c}\text { Moldanubian Zone } \\
\text { KMV } 96 \text { Bída }\end{array}$}} \\
\hline & \multicolumn{2}{|c|}{ KMV 118 Roztěž } & \multirow{2}{*}{\multicolumn{2}{|c|}{$\begin{array}{c}\text { KMV 95d Bořetice } \\
\text { Omp }\end{array}$}} & \multirow{2}{*}{$\begin{array}{c}\frac{\text { K 30b Úhrov }}{\text { Omp }} \\
\text { matrix }\end{array}$} & \multicolumn{2}{|c|}{ KMV 103d Spačice } & & & \\
\hline & $\frac{\text { Omp }}{\text { incl. in Grt }}$ & $\frac{\mathrm{Cpx}}{\text { symplectite }}$ & & & & $\begin{array}{c}\text { Omp } \\
\text { matrix }\end{array}$ & $\frac{\text { Cpx }}{\text { symplectite }}$ & $\frac{\text { Omp }}{\text { incl. in Grt }}$ & $\begin{array}{c}\text { Omp } \\
\text { incl. in Grt }\end{array}$ & $\begin{array}{c}\text { Cpx } \\
\text { symplectite }\end{array}$ \\
\hline \multicolumn{11}{|l|}{ (wt. \%) } \\
\hline $\mathrm{SiO}_{2}$ & 55.28 & 53.19 & 55.55 & 54.80 & 52.59 & 54.65 & 53.04 & 53.59 & 54.50 & 49.66 \\
\hline $\mathrm{TiO}_{2}$ & 0.04 & 0.09 & 0.15 & 0.21 & 0.44 & 0.26 & 0.43 & 0.28 & 0.12 & 0.77 \\
\hline $\mathrm{Cr}_{2} \mathrm{O}_{3}$ & 0.04 & 0.00 & 0.04 & 0.06 & 0.04 & 0.00 & 0.00 & 0.04 & 0.00 & 0.10 \\
\hline $\mathrm{Al}_{2} \mathrm{O}_{3}$ & 9.47 & 1.44 & 14.92 & 8.26 & 11.26 & 9.47 & 3.32 & 9.26 & 10.92 & 5.61 \\
\hline $\mathrm{Fe}_{2} \mathrm{O}_{3}$ & 0.46 & 2.61 & 0.64 & 2.45 & 0.93 & 0.29 & 0.64 & 1.88 & 3.65 & 3.23 \\
\hline $\mathrm{FeO}$ & 3.49 & 4.65 & 0.95 & 2.87 & 3.75 & 4.80 & 5.27 & 4.58 & 1.66 & 5.47 \\
\hline $\mathrm{MnO}$ & 0.01 & 0.05 & 0.08 & 0.03 & 0.00 & 0.00 & 0.00 & 0.00 & 0.00 & 0.08 \\
\hline $\mathrm{MgO}$ & 9.36 & 13.63 & 6.94 & 9.72 & 9.12 & 9.81 & 14.00 & 9.43 & 8.65 & 12.64 \\
\hline $\mathrm{Na}_{2} \mathrm{O}$ & 5.79 & 1.36 & 8.04 & 5.08 & 4.86 & 4.92 & 1.24 & 4.88 & 6.68 & 1.59 \\
\hline Total & 98.82 & 99.17 & 99.68 & 100.63 & 99.51 & 100.30 & 99.91 & 100.47 & 100.89 & 99.30 \\
\hline \multicolumn{11}{|c|}{ apfu (per 60$)$} \\
\hline $\mathrm{Si}$ & 1.993 & 1.978 & 1.952 & 1.962 & 1.905 & 1.960 & 1.951 & 1.940 & 1.949 & 1.867 \\
\hline $\mathrm{Ti}$ & 0.001 & 0.002 & 0.004 & 0.006 & 0.012 & 0.007 & 0.012 & 0.008 & 0.003 & 0.022 \\
\hline $\mathrm{Cr}$ & 0.001 & 0.000 & 0.001 & 0.002 & 0.001 & 0.000 & 0.000 & 0.001 & 0.000 & 0.003 \\
\hline $\mathrm{Al}$ & 0.403 & 0.063 & 0.618 & 0.349 & 0.481 & 0.400 & 0.144 & 0.395 & 0.461 & 0.249 \\
\hline $\mathrm{Fe}^{3+}$ & 0.013 & 0.073 & 0.017 & 0.066 & 0.025 & 0.008 & 0.018 & 0.051 & 0.098 & 0.091 \\
\hline $\mathrm{Fe}^{2+}$ & 0.105 & 0.145 & 0.028 & 0.086 & 0.114 & 0.144 & 0.162 & 0.139 & 0.050 & 0.172 \\
\hline $\mathrm{Mn}$ & 0.000 & 0.002 & 0.002 & 0.001 & 0.000 & 0.000 & 0.000 & 0.000 & 0.000 & 0.003 \\
\hline $\mathrm{Mg}$ & 0.503 & 0.756 & 0.363 & 0.519 & 0.492 & 0.524 & 0.768 & 0.509 & 0.461 & 0.708 \\
\hline $\mathrm{Na}$ & 0.405 & 0.098 & 0.548 & 0.352 & 0.341 & 0.342 & 0.088 & 0.342 & 0.463 & 0.116 \\
\hline \multicolumn{11}{|l|}{$(\mathrm{mol} . \%)$} \\
\hline $\mathrm{Jd}$ & 0.40 & 0.04 & 0.55 & 0.31 & 0.32 & 0.33 & 0.07 & 0.29 & 0.37 & 0.03 \\
\hline En & 0.25 & 0.38 & 0.18 & 0.26 & 0.25 & 0.26 & 0.38 & 0.25 & 0.23 & 0.35 \\
\hline Fs & 0.05 & 0.07 & 0.01 & 0.04 & 0.06 & 0.07 & 0.08 & 0.07 & 0.02 & 0.09 \\
\hline Wo & 0.28 & 0.43 & 0.21 & 0.31 & 0.28 & 0.29 & 0.41 & 0.29 & 0.26 & 0.35 \\
\hline $\mathrm{X}_{\mathrm{Mg}}\left(\mathrm{Fe}_{\mathrm{TOT}}\right)$ & 0.81 & 0.78 & 0.89 & 0.77 & 0.78 & 0.78 & 0.81 & 0.73 & 0.76 & 0.73 \\
\hline
\end{tabular}

* $\mathrm{KHC}=$ Kutná Hora Complex

\subsubsection{KMV82 Miškovice}

A flat rocky formation was exposed in massive and resistant light $\mathrm{Ky}-\mathrm{Grt}$ granulite mostly retrogressed into Bt-Ms granulite gneiss at the bottom of the valley, in western outskirts of the Miškovice village. One of the outcropping blocks in the middle of a stream is formed by darker quartz-rich kyanite-garnet granulite with $\mathrm{Na}$-rich clinopyroxene and ternary feldspars, the latter containing lamellar mesoperthitic exsolutions. The chemical composition of this mafic granulite is different from the other studied HP rocks. It has calc-alkaline andesitic to basaltic character and is rich in $\mathrm{SiO}_{2}, \mathrm{Na}_{2} \mathrm{O}, \mathrm{K}_{2} \mathrm{O}$ and depleted in $\mathrm{MgO}, \mathrm{NiO}$ and $\mathrm{CaO}$ (Fig. 2). The Cpx-granulite shows both the relict Grt-Ky-Pl-Qtz-Cpx mineral assemblage and several types of fine-grained replacement aggregates of sillimanite, margarite, clinopyroxene II, biotite, muscovite and plagioclase, indicating polymetamorphic overprint (Fig. 3e).

\subsubsection{KMV116 Doubravčany South}

The Grt-Cpx-Qtz-Hbl-Rt rock is a new occurrence of banded metabasite found within the Kouřim Unit orthogneiss, indicating the conditions of upper amphibolite facies in the area. Chemically, this rock is dacitic and distinct from other $\mathrm{HP}$ rocks in high $\mathrm{Al}_{2} \mathrm{O}_{3}, \mathrm{CaO}$, $\mathrm{P}_{2} \mathrm{O}_{5}, \mathrm{FeOt}$ and $\mathrm{FeO} /(\mathrm{FeO}+\mathrm{MgO})$ and $\mathrm{Sr}$; on the other hand, it is depleted in $\mathrm{MgO}, \mathrm{SiO}_{2}, \mathrm{Na}_{2} \mathrm{O}, \mathrm{Cr}, \mathrm{Ni}$ and $\mathrm{Y}$. Rounded-to-subhedral garnet consists mostly of Alm-Grs 


\section{a KMV118 - Roztěž, inner part of KHC}

mol. \%

90 outer rim inner zone core

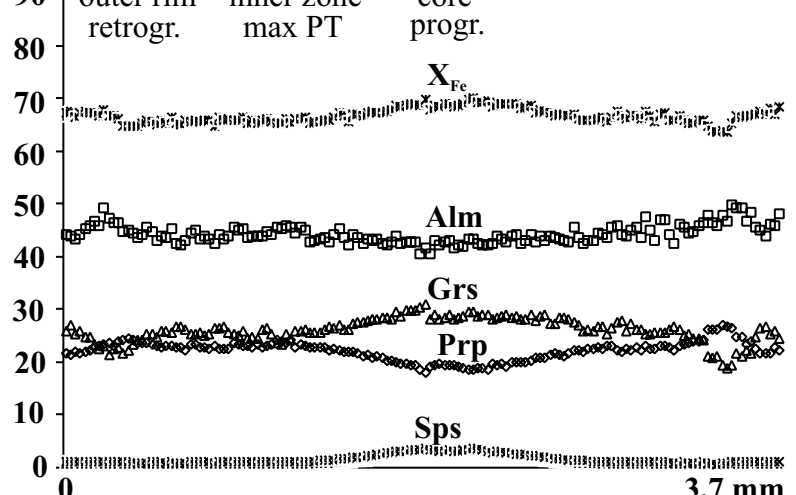

C KMV95d - Bořetice, inner part of KHC mol. \%
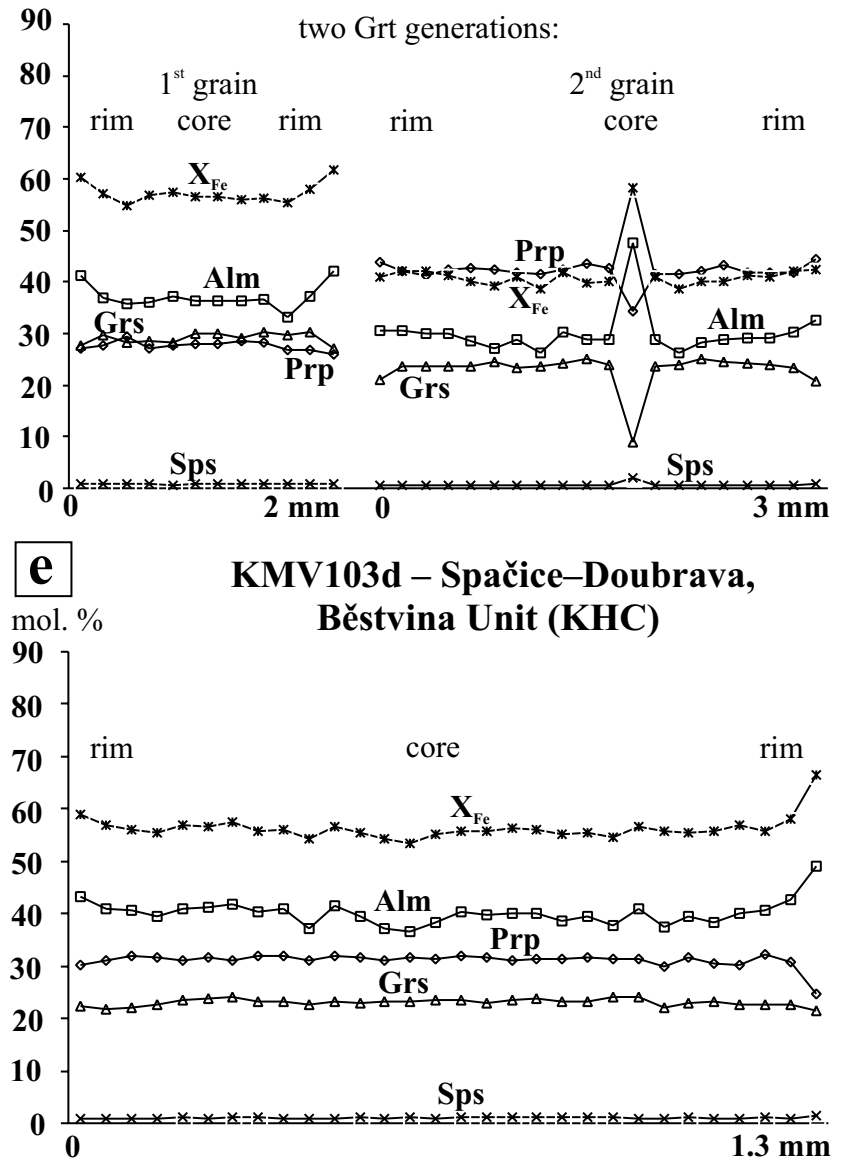

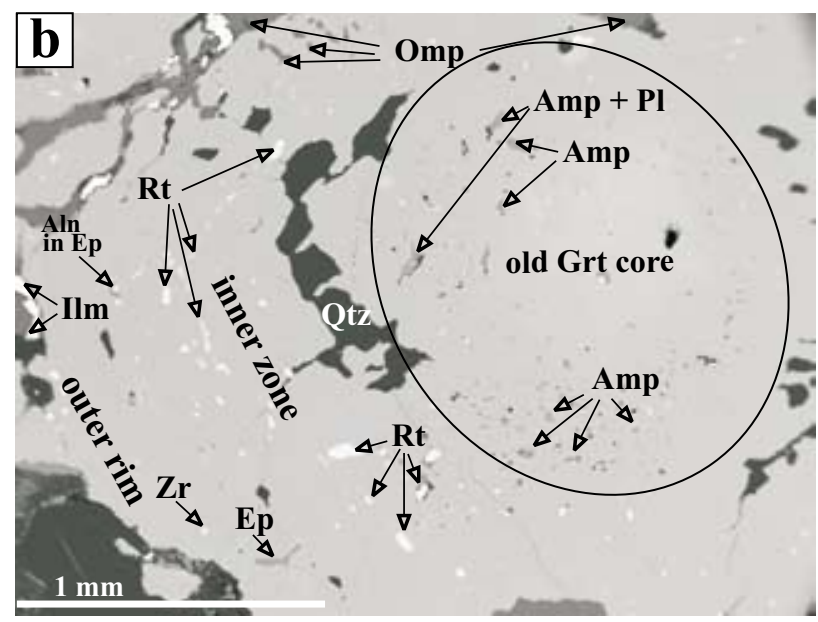

d KMV30b - Úhrov, Běstvina Unit (KHC) mol. \%

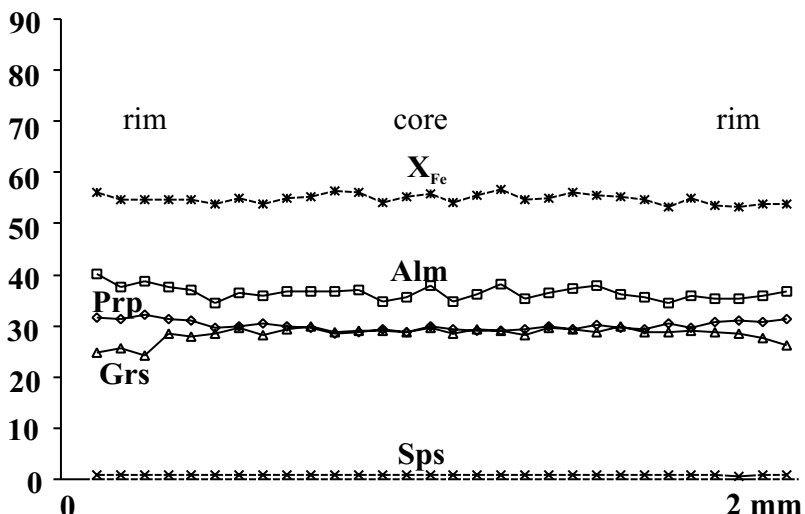

f KMV109b - Borovský Creek, MZ

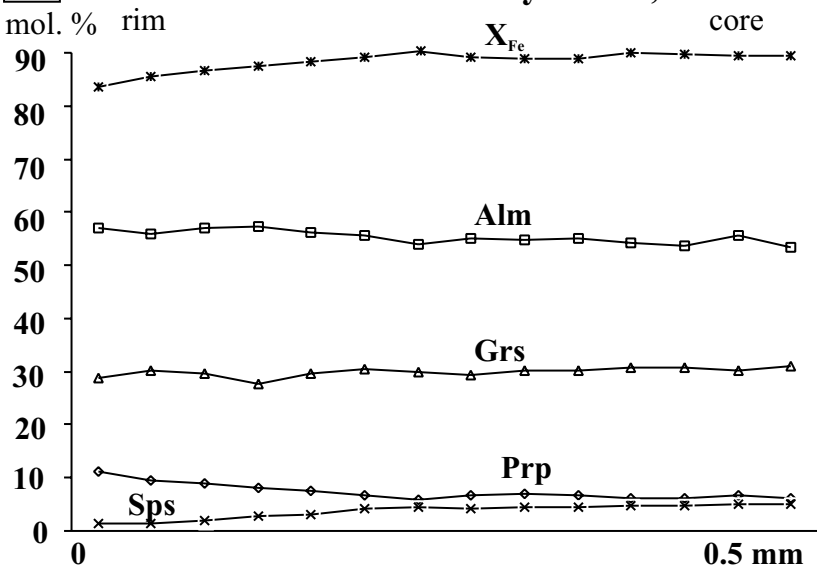

Fig. 5 Composition of eclogite garnet from the Kutná Hora Complex (KHC) and the adjacent part of the Moldanubian Zone (MZ). a - Garnet zoning pattern in the eclogite KMV118 from Roztěž (inner part of the KHC); b - Back-scattered electron image of garnet from the Roztěž eclogite showing distribution of relict inclusions.

Garnet zoning patterns of additional eclogite samples: c - KMV95d from Bořetice (KHC); d - KMV30b from Úhrov (KHC - Běstvina Unit); e - KMV103d from Spačice-Doubrava (KHC - Běstvina Unit); f - KMV109b from the Borovský Creek (MZ). 
components ( $\operatorname{Alm}_{43-51} \operatorname{Prp}_{3-6} \mathrm{Grs}_{34-44} \mathrm{Sps}_{2-7}$ mol. \%) with inclusions of hornblende $\left(1 \mathrm{wt} . \%\right.$ of $\left.\mathrm{Na}_{2} \mathrm{O}\right)$ and quartz. Garnet is in equilibrium with green euhedral and lathshaped, iron-rich amphibole, globular low-Na diopsidic clinopyroxene and quartz (Fig. 3f). Matrix plagioclase occurs mostly in aggregates with small Cpx crystals, which may suggest some replacement mechanism. As the major-element composition is similar to some skarns from KHC (see also Pertoldová et al. this volume), the banded rock may belong to calc-silicate rocks.

\subsubsection{KMV30b Úhrov}

The Běstvina unit of the KHC generally provided several locations with very well-preserved eclogites and garnetites carrying equilibrium HP assemblage, some of them almost without retrograde reactions. One such eclogite sample was found in blocks above a temporarily opened small quarry in garnet peridotite near Úhrov. The chemical composition reveals similarities with kyanite eclogites from the Běstvina Unit and corresponds to tholeiitic basalt enriched in $\mathrm{Al}_{2} \mathrm{O}_{3}, \mathrm{FeO}, \mathrm{MgO}, \mathrm{P}_{2} \mathrm{O}_{5}$ and depleted in $\mathrm{SiO}_{2}$ and $\mathrm{K}_{2} \mathrm{O}$ (Fig. 2). Both exsolution of lamellar sodic plagioclase from omphacite and Hbl-An kelyphite nucleation along garnet rims are only at initial stages, and most of the peak minerals are well preserved (Fig. 4a). Garnet grains show almost flat compositional pattern with a rimward decrease in Grs balanced by an increase of both Alm and Prp (Alm $\operatorname{Al}_{38-40} \operatorname{Prp}_{30-32} \mathrm{Grs}_{30-25}, \mathrm{Sps}_{\leq 1} \mathrm{~mol}$. $\%$, Fig. $5 \mathrm{~d}$ ), and maximum $\mathrm{X}_{\mathrm{Jd}}$ in the omphacite reaches $32 \%\left(4.86\right.$ wt. $\left.\% \mathrm{Na}_{2} \mathrm{O}\right)$.

\subsubsection{KMV103 Spačice - Doubrava River}

A several-metre-long lens of kyanite eclogite was found on the right bank of the Doubrava River near Spačice. The river section exposed slightly banded fresh eclogites with penetrative amphibolization along the fractures bearing numerous rutile grains up to $1 \mathrm{~cm}$ in size. Eclogite is basically of the Grt-Omp-Qtz-Rt type (Fig. 4b), but kyanite, apatite, $\mathrm{Kfs}$ and $\mathrm{Hbl}$ are present in limited amounts. Retrograde changes affected omphacite $\left(\mathrm{X}_{\mathrm{Jd}}=31 \mathrm{~mol}\right.$. $\%, \mathrm{Na}_{2} \mathrm{O}=4.97$ wt. \%), thus producing seriate lamellar $\mathrm{Cpx}-\mathrm{Pl}$ symplectites. Kyanite was transformed into small fibrous clusters with dominant margarite. The amount of garnet varies in the individual bands, some of them being almost monomineralic garnetite. The main garnet components display low variations $\left(\mathrm{Alm}_{37-44} \operatorname{Prp}_{30-33} \mathrm{Grs}_{22-24}\right.$ $\mathrm{Sps}_{0.5-0.8}$ mol. \%) except of a narrow diffusion rim (Fig. 5e). The chemical composition exhibits similarities to HP rocks from the Běstvina Unit, but contains higher $\mathrm{SiO}_{2}$, $\mathrm{CaO}, \mathrm{MgO}, \mathrm{Sr}$, and low $\mathrm{TiO}_{2}, \mathrm{~K}_{2} \mathrm{O}, \mathrm{FeOt}, \mathrm{Zr}$, and $\mathrm{Y}$ and high-Mg tholeiite basaltic whole-rock composition. This occurrence is newly described, so the characteristics of this eclogite are compared to other eclogites from the Běstvina Unit, newly sampled from already known locations like Spačice and Úhrov.

\subsubsection{KMV96 Bída}

Migmatite-dominated area along the boundary of the MZ and KHC in the SE part of the studied area provided several findings of eclogites and granulites, most of them in loose blocks. One of them is from the Bída Hill near Hájek, northeast of Česká Bělá. This retrogressed GrtOmp-Rt eclogite consists of symplectitic matrix and rounded and irregular garnets $\left(\mathrm{Alm}_{46-48} \operatorname{Prp}_{24} \mathrm{Grs}_{24-27} \mathrm{Sps}_{1}\right)$ with secondary plagioclase (Fig. 4c). Omphacite in rare relict grains displays a highly sodic composition reaching up to 6.68 wt. $\%$ of $\mathrm{Na}_{2} \mathrm{O}\left(\mathrm{X}_{\mathrm{Jd}}=37 \mathrm{~mol} . \%\right)$. Chemically is this eclogite slightly depleted in $\mathrm{CaO}$ and is similar in most of major elements to the magnesian tholeiitic eclogites of the Běstvina Unit (Fig. 2).

\subsubsection{KMV109 Borovský Creek}

Well-preserved HP rocks were sampled from the upper ramp of the Borovský Creek Valley (left bank) west of Havlíčkova Borová (Štědrá ed. 2009). Medium- to finegrained eclogites consist of Omp-Grt-Qtz-Rt-Ky assemblage (Fig. 4d). Omphacite grains $\left(\mathrm{Na}_{2} \mathrm{O}=5.13\right.$ wt. \%, $\mathrm{X}_{\mathrm{Jd}}=35 \mathrm{~mol} . \%$ ) are partially replaced by symplectite along rims. Equant garnet grains are either homogeneous or zoned (Fig. 5f), containing inclusions of $\mathrm{Cpx}$ and Rt (sample KMV110a: $\mathrm{Alm}_{30-48} \operatorname{Prp}_{38-44} \mathrm{Grs}_{11-22} \mathrm{Sps}_{\leq 1}$, sample KMV110b: $\operatorname{Alm}_{54-57} \operatorname{Prp}_{6-11} \mathrm{Grs}_{3} 0 \mathrm{Sps}_{\leq 0.5-1.5}$ ). The garnets are rimmed by decompression plagioclase and kelyphitic corona of pargasitic amphibole and Ca-plagioclase. Accessory kyanite was replaced by minor dark aggregates of Sp-An symplectite. Matrix minerals enclose irregular grains of accessory sulphides chalcopyrite, pyrite and pentlandite.

\subsubsection{KMV110 Krátká Ves}

Eclogite, found in blocks together with Ky-Grt gneiss, shows a high content of garnet $\left(\mathrm{Alm}_{39-44} \operatorname{Prp}_{25-27} \mathrm{Grs}_{27-30}\right.$ $\mathrm{Sps}_{\leq 0.1}$ ), quartz, rutile, apatite, and pyroxene in cores of grains with external zones replaced by HP brown amphibole rich in $\mathrm{Na}$ and $\mathrm{Ti}$, and relict biotite and ilmenite (Fig. 4e). The sodic $\mathrm{Cpx}$ reaches just medium $\mathrm{Na}_{2} \mathrm{O}$ contents of c. 2 wt. $\%\left(\mathrm{X}_{\mathrm{Jd}}=0.13 \mathrm{~mol}\right.$ \%). Garnet grains are rimmed by a typical coarse-lamellar corona of $\mathrm{Hbl}-\mathrm{Ca}-\mathrm{Pl}$ and, in the second stage, by domainal Opx-An corona. Plagioclase in matrix is secondary. Several generations of younger olive green to green amphibole, together with 


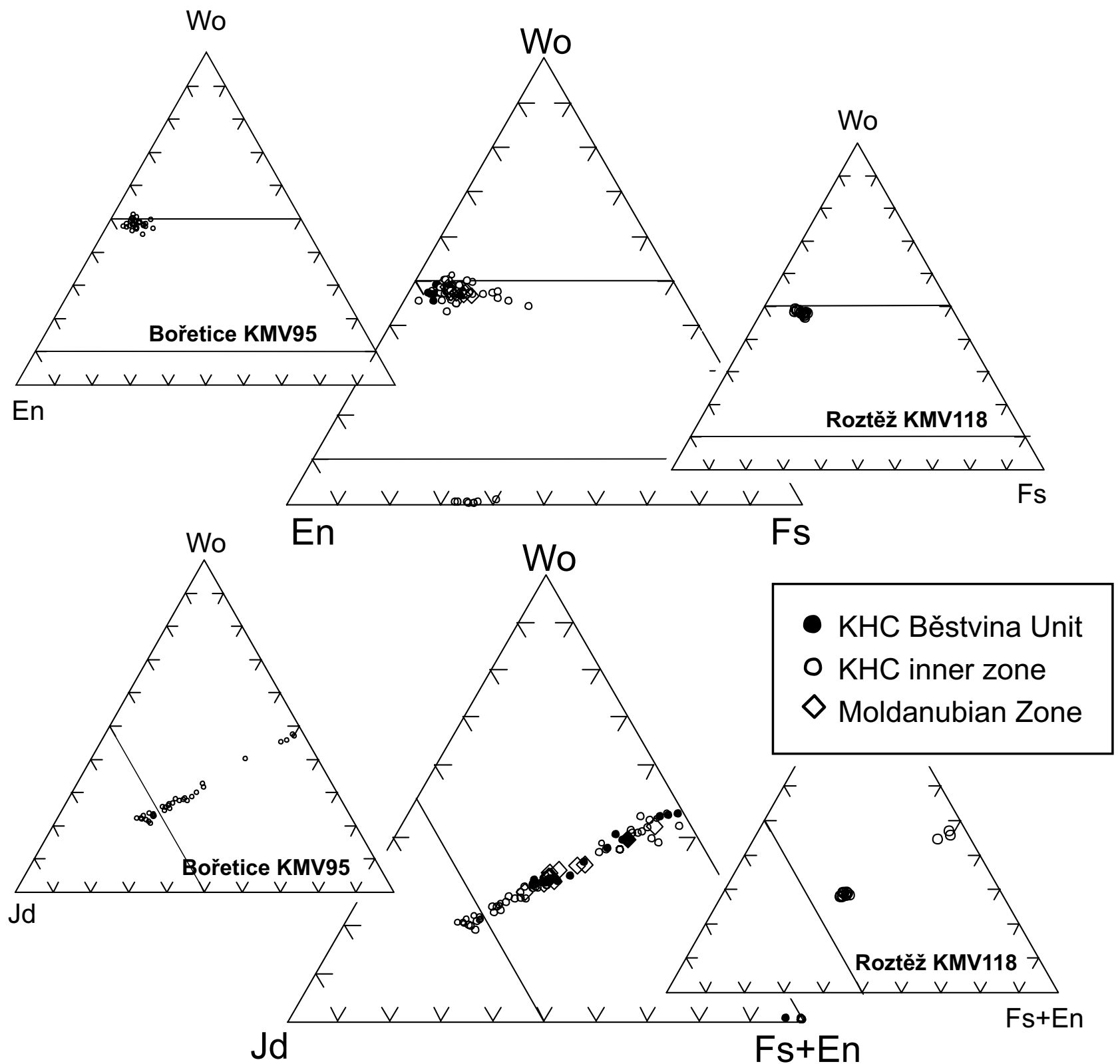

Fig. 6 Composition of clinopyroxene and orthopyroxene from the studied eclogites in the ternary diagrams En-Fs-Wo (above) and Jd-(Fs + En)Wo (below). The composition of pyroxenes from the KHC, Běstvina Unit and Moldanubian eclogites shown in the central diagrams is similar, although each sample may contain secondary Opx and several generations of Cpx with variable $\mathrm{X}_{\mathrm{Jd}}$. The composition of HP clinopyroxene from the Roztěž eclogite and the Bořetice kyanite-bearing eclogite are shown separately in smaller diagrams.

chlorite, carbonates, epidote, titanite, Ti-magnetite and sulphides are randomly distributed within the matrix, due to retrogression. The rock resembles a gabbroic rock with $\mathrm{HP}$ and later retrograde overprint.

Several blocks of HP rock with the assemblage GrtOmp-Hbl-Bt-Pl-Ru-Ilm was found near Oudoleň NW of Krátká Ves. This mafic granulite complementing the set of eclogite samples from the Moldanubian Zone is also shown (Fig. 4f).

\subsection{Metamorphic record in eclogites}

\subsubsection{Conventional geothermobarometry}

Conventional exchange geothermobarometry allows only limited application to HP metabasic rocks either due to simple mineral composition, or presence of amphiboles. The validity of the most relevant calibrations using microprobe data was widely discussed by a number of au- 

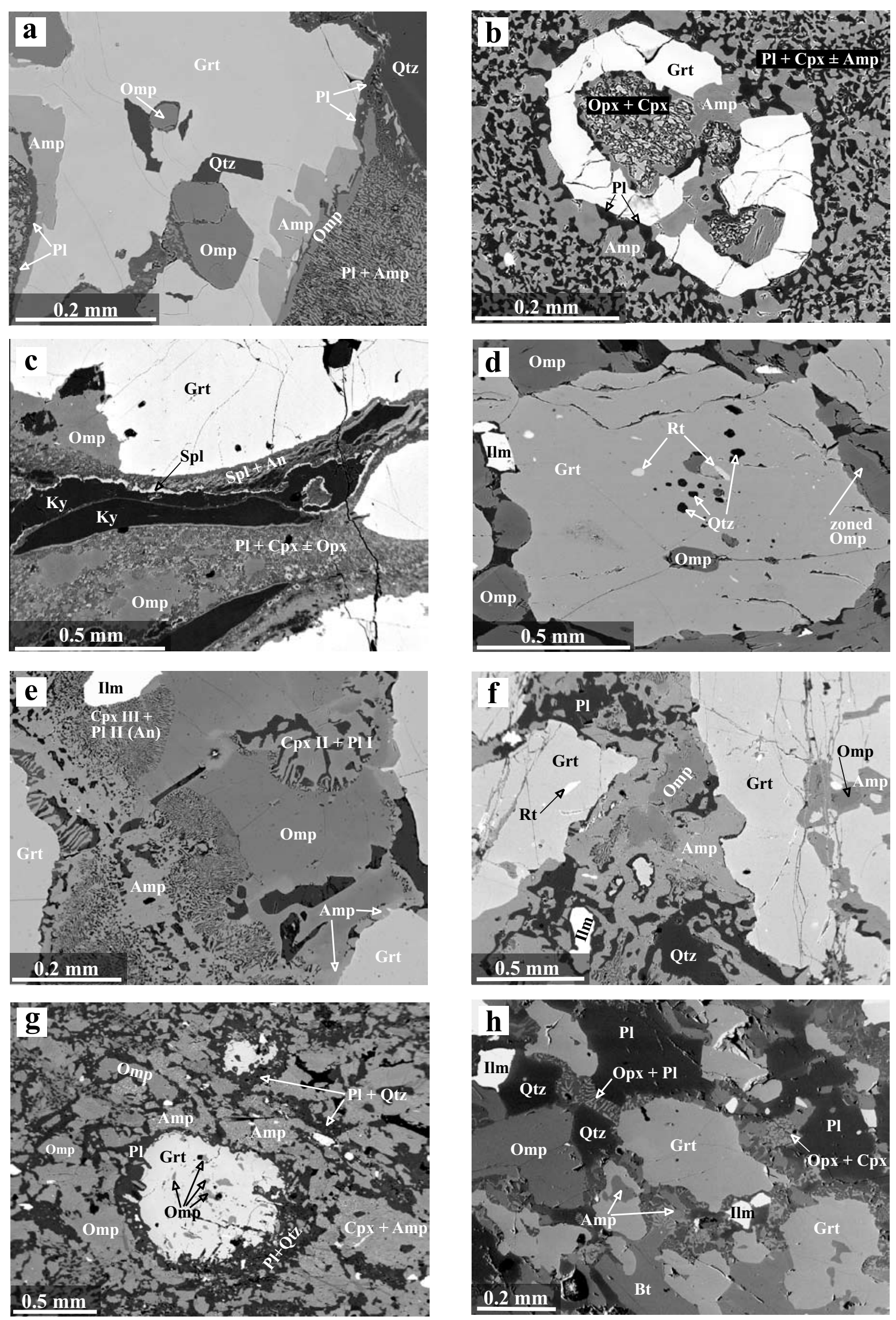
thors, some of which were highly critical about the usage of raw data with only total iron determined (e.g. Sobolev et al. 1999). With time, however, some of them admitted the legitimacy of these methods for rocks with suitable composition (e.g., Štípská and Powell 2005) or proposed new net transfer calibrations using Mg-end member minerals (Ravna and Terry 2004). Some metabasites studied contain HP assemblages with kyanite, and thus satisfy conditions for application of the latter method. On the other hand, the absence of phengite in these eclogites sets limits of the method and increases error intervals.

The studied eclogites show a variable degree of equilibration under the HP conditions and subsequent stages (Fig. 7). Especially rocks derived from a gabbroic protolith retain the microtextural and mineralogical indications of the precursor (Tři Dvory, Krátká Ves). These rocks contain pyroxenes with lower $\mathrm{X}_{\mathrm{Jd}}$ and pseudomorphs after magmatic minerals $(\mathrm{Cpx}, \mathrm{Pl}, \mathrm{Ol})$.

Garnets in all the samples are usually well crystallized, form rounded, oval or occasionally corroded grains, except for skeletal types from Tři Dvory and Doubravčany. Deformed garnet from porphyroclastic and recrystallized mylonite from Bořetice represents the other exception (Fig. 3c). Minerals included in garnet are important tracers of metamorphic history together with the growth compositional zoning. The samples from Miškovice, Krátká Ves and Oudoleň contain plagioclase as an equilibrium phase, thus indicating granulite-facies conditions. In case of Cpx-amphibolite from Doubravčany, the maximum P-T correspond to upper amphibolite facies.

The growth-zoning pattern of a large garnet grain (3.7 $\mathrm{mm}$ in diameter) from Roztěž eclogite suggests several oscillations in P-T conditions. The garnet composition supported by presence of mineral inclusions present in the respective zones, were utilized for reconstruction of the P-T path. The inclusions document a generally

$$
\text { « }
$$

Fig. 7 Back-scattered electron images for the studied eclogites (KHC $=$ Kutná Hora Complex, BU = Běstvina Unit, MZ = Moldanubian Zone). a - A detail of a garnet grain with an inclusion of Omp and incipient growth of secondary $\mathrm{Hbl}$ and $\mathrm{Pl}$ along garnet rim in the eclogite KMV118 from Roztěž (KHC); b - Skeletal Grt around the relict Opx-Cpx aggregate and the partially amphibolized diablastic matrix in the eclogite KMV 76 from Tři Dvory (KHC); c - A garnet grain with multiphase inclusions, extremely elongated kyanite grains rimmed by fine-grained $\mathrm{Sp}-\mathrm{Pl}$ symplectite, accompanied by grain-size reduction of omphacite due to mylonitization in the kyanite eclogite KMV 95 from Bořetice (KHC); d - Qtz, Rt and Omp inclusions in garnet grain in the eclogite KMV103d from Spačice-Doubrava (BU); e - Several evolutionary stages of decompressional symplectites gradually replacing omphacite in the eclogite KMV30b from Úhrov (BU); f - An irregular disequilibrium texture of Grt, Omp, CpxII, Hbl, Pl and Qtz in the partially retrogressed eclogite KMV96 from Bída (MZ); g - High-pressure garnet with omphacite inclusions and partially retrogressed matrix in the eclogite KMV109b from the Borovský Creek (MZ); h - Formation of reaction textures in the Hbl-bearing eclogite KMV110b from Krátká Ves (MZ). prograde trend from amphibolite (Amp-Ab) to eclogite facies (Rt-Omp) with omphacites of the highest $X_{\mathrm{Id}}$ in the outer zone. Some Grt grains from the Poličany eclogite (KMV44) also contain the oldest core $\left(\mathrm{Alm}_{43-62}\right.$ $\operatorname{Prp}_{8-23} \operatorname{Grs}_{12-30} \mathrm{Sps}_{2-6}$ mol. \%); on the other hand, there is also evidence for subsequent thermal relaxation and retrogression.

The rather good state of preservation of clinopyroxenes in most samples allows us to record variations in $\mathrm{X}_{\mathrm{Jd}}$ and to provide evidence for a robust pressure record in metabasic rocks in the $\mathrm{KHC}$ core. Values of $\mathrm{X}_{\mathrm{Jd}}$ in omphacite of 35-50 mol. \% were found for several eclogites for the first time. These numbers are even higher that in the Běstvina Unit, so far assumed to indicate the most extreme P-T conditions in the KHC (Fig. 6). Surprisingly high $\mathrm{X}_{\mathrm{Jd}}{ }^{\mathrm{Cpx}}$ was found in eclogites from minor occurrences at Bída, Krátká Ves and the Borovský Creek in the Moldanubian Zone $\left(\mathrm{X}_{\mathrm{Jd}}=35-37 \mathrm{~mol}\right.$. \%).

Several generations of amphiboles can be observed. The oldest metamorphic history is documented by their inclusions in garnet, although these minor grains were partly affected by diffusion. Green and brownish amphiboles of pargasitic and tschermakitic composition often form kelyphites around garnets, and olive green high Na-edenites formed during the final stages of the HP event. The youngest population of the actinolite-tremolite series replaces garnets and clinopyroxenes during local low-grade retrograde recrystallization.

Pressure were estimated on the basis of the $\mathrm{Cpx}-\mathrm{Qtz}$ equilibrium (Holland 1980). The minimum $\mathrm{P}$ derived from $\mathrm{X}_{\mathrm{Jd}}$ in $\mathrm{Cpx}$ from the Roztěž eclogite (Gasparik and Lindsley 1980) at $\mathrm{T}=1000{ }^{\circ} \mathrm{C}$ is $2.16 \mathrm{GPa}$. For the main rock-forming minerals, conventional methods can yield only minimum pressure estimates depending on incorporation of the jadeite component into $\mathrm{Cpx}$, and by thermometry from the Grt-Cpx pairs. The linear dependence of the jadeite-quartz thermometer and its intersection with the garnet-clinopyroxene $\mathrm{Fe} / \mathrm{Mg}$ exchange thermometers by Krogh (1988) and Ganguly et al. (1996) was used. The equilibrium temperatures inferred for cores of Omp inclusion (with composition analogous to matrix grains, i.e., not substantially affected by later diffusion) and neighbouring garnet were calculated. Both the thermometers provided a good fit; the resulting data indicate a thermal interval of $750-810^{\circ} \mathrm{C}$ at $2.15-2.35 \mathrm{GPa}$ for this eclogite (Fig. 8). These two calibrations were used also for other eclogites from the $\mathrm{KHC}$ and $\mathrm{MZ}$ with following results: eclogite from Bída $-660{ }^{\circ} \mathrm{C} / 1.9-2.0 \mathrm{GPa}$ resp. $825^{\circ} \mathrm{C} / 2.2 \mathrm{GPa}$, eclogite from Úhrov $-825^{\circ} \mathrm{C} / 2.3 \mathrm{GPa}$ resp. $947{ }^{\circ} \mathrm{C} / 2.55 \mathrm{GPa}$, and Ky eclogite from Spačice $845^{\circ} \mathrm{C} / 2.3 \mathrm{GPa}$ resp. $920^{\circ} \mathrm{C} / 2.5 \mathrm{GPa}$.

Relatively good prospects for calculations of P-T conditions are provided by the kyanite eclogite from Bořetice. This rock is extremely rich in $\mathrm{Al}_{2} \mathrm{O}_{3}(18.46$ wt. \%) and 


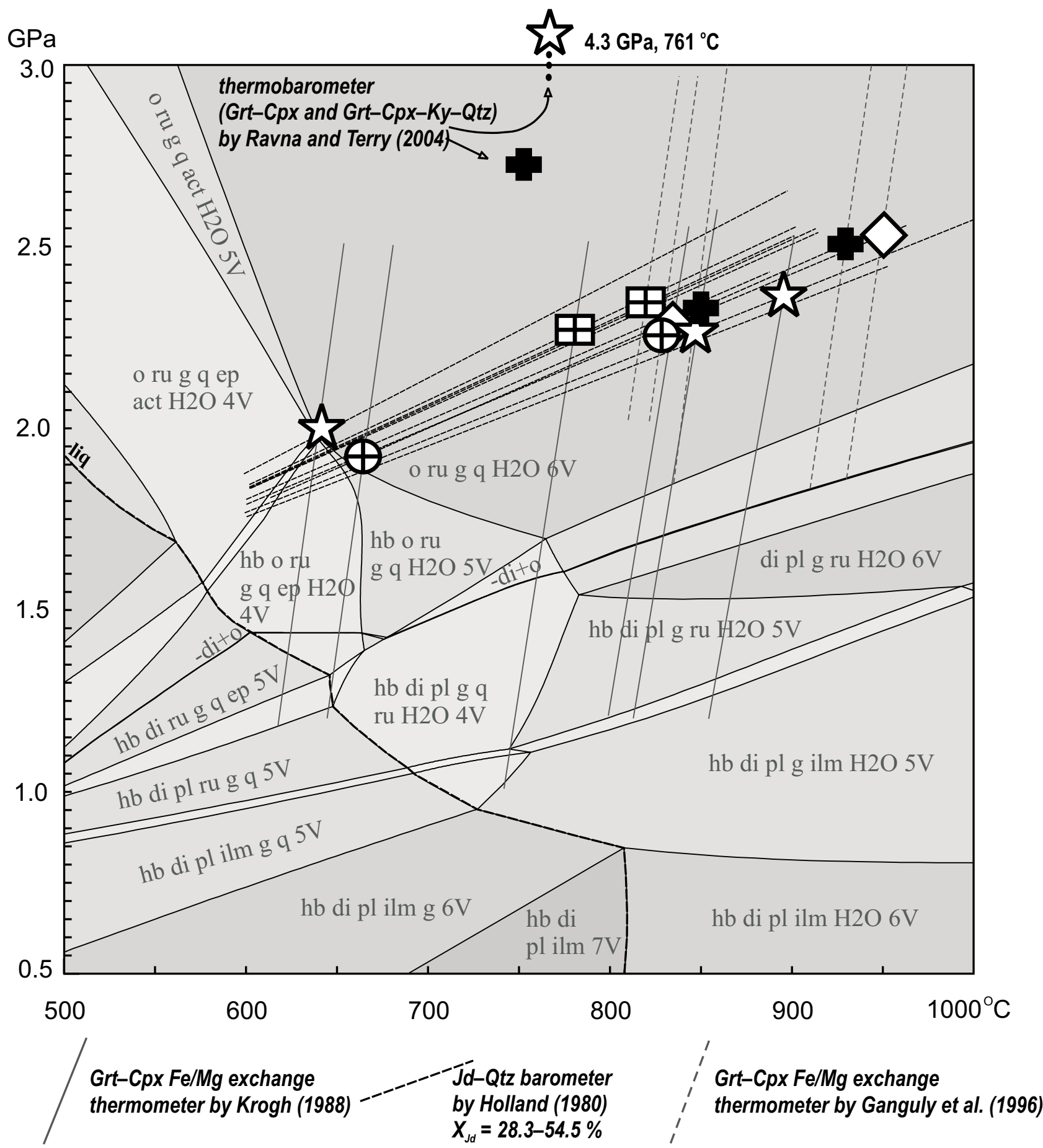

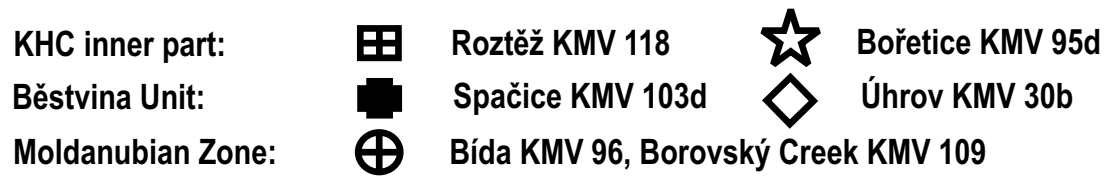

Fig. 8 Results of conventional geothermobarometry for the representative eclogite samples from the inner part of the Kutná Hora Complex, the Běstvina Unit, and from the adjacent part of the Moldanubian Zone in the P-T diagram. Background multivariant fields correspond to the simplified pseudosection shown in Fig. 9. 


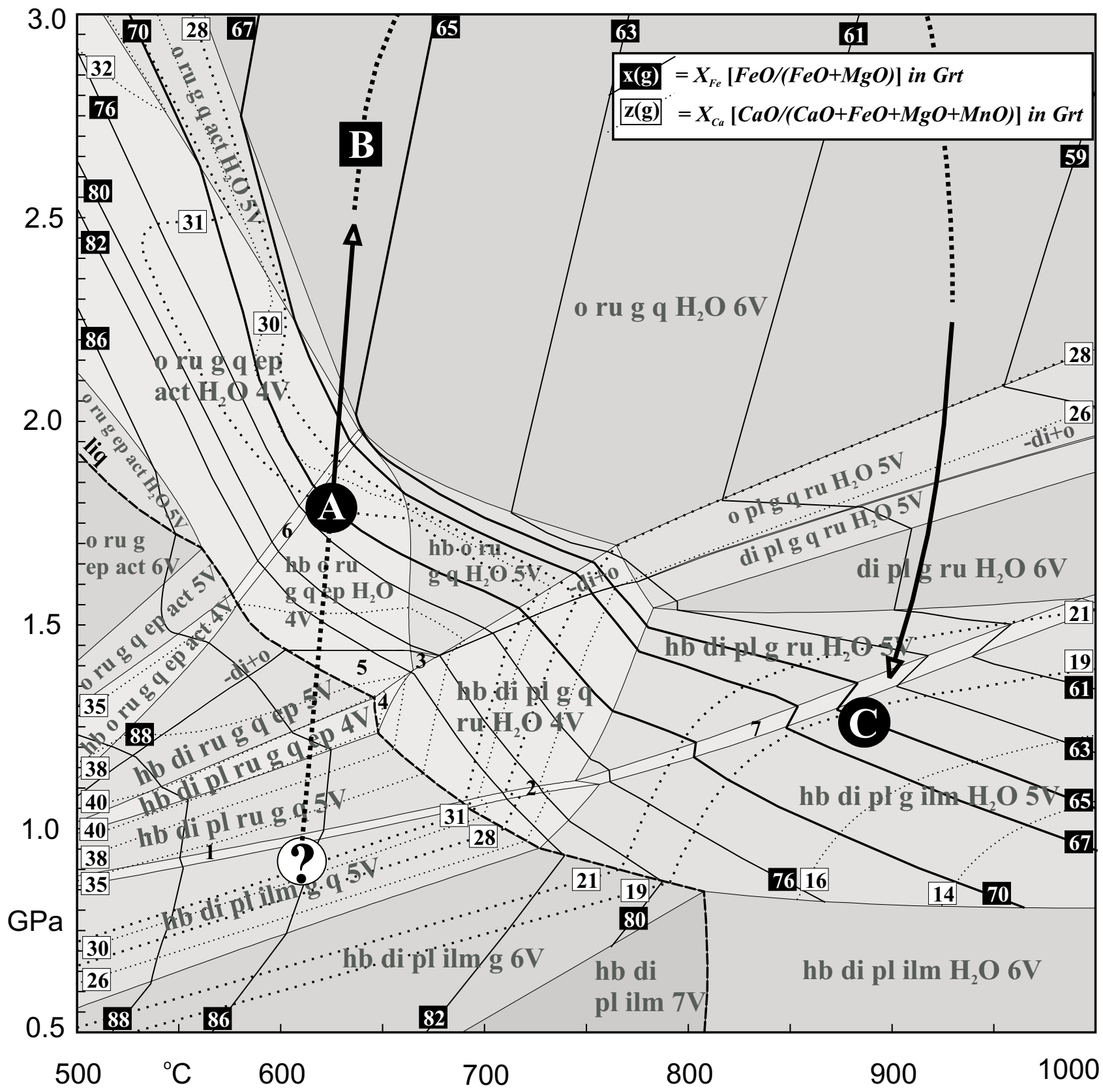

Fig. 9 The PTX pseudosection of the Roztěž eclogite (sample KMV118) calculated by the THERmOCALC 3.31 NCFMASHTO system (3.43 $\mathrm{H}_{2} \mathrm{O}$, $49.28 \mathrm{SiO}_{2}, 8.45 \mathrm{Al}_{2} \mathrm{O}_{3}, 12.94 \mathrm{CaO}, 11.24 \mathrm{MgO}, 10.50 \mathrm{FeO}, 3.07 \mathrm{Na}_{2} \mathrm{O}, 0.58 \mathrm{TiO}_{2}, 0.52 \mathrm{O}$ mol. \%). Thin dotted lines mark isopleths of grossular component " $\mathrm{z}(\mathrm{g})=\mathrm{X}_{\mathrm{Ca}}[\mathrm{CaO} /(\mathrm{CaO}+\mathrm{FeO}+\mathrm{MgO}+\mathrm{MnO})]$ ", thin solid lines are $\mathrm{X}_{\mathrm{Fe}}$ isopleths " $\mathrm{x}(\mathrm{g})=\mathrm{X}_{\mathrm{Fe}}[\mathrm{FeO} /(\mathrm{FeO}+\mathrm{MgO})]$ ". The outlined heavy isopleths are important for P-T path definition: point $\mathbf{A}$ is the intersection of the garnet core values $\left(\mathrm{X}_{\mathrm{Ca}}=31, \mathrm{X}_{\mathrm{Fe}}=70\right)$ indicating the continuous prograde part of the P-T path at $1.75 \mathrm{GPa}$ and $630^{\circ} \mathrm{C}$ (bold dotted line to A). Considering the plagioclase presence in the Grt core, garnet must have started to grow at plagioclase stability field below $1.15 \mathrm{GPa}$ ("'?"), line B represents a possible area of max. P-T conditions estimated from $\mathrm{X}_{\mathrm{Fe}}$ inner zone values $\left(\mathrm{X}_{\mathrm{Fe}}=65-66\right)$ isopleths are directed from $2.2 \mathrm{GPa}$ to (ultra-) high pressure at $c .600-650{ }^{\circ} \mathrm{C}$ (bold full and dotted line). The Grs value of the inner rim $\left(\mathrm{X}_{\mathrm{Ca}}=28\right)$ corresponds to the whole Omp-Rt-Grt-Qtz- $\mathrm{H}_{2} \mathrm{O}$ (or liq) stability field in the pseudosection, point $\mathbf{C}$ at the intersection of outer rim garnet isopleths $\left(\mathrm{X}_{\mathrm{Ca}}=19, \mathrm{X}_{\mathrm{Fe}}=65\right)$ represents the retrograde $\mathrm{MP} / \mathrm{HT}$ conditions at $1.25 \mathrm{GPa}$ and $890{ }^{\circ} \mathrm{C}$.

Mineral abbreviations in the diagram: $\mathrm{hb}$ - hornblende, act - actinolite, o - omphacite, di - diopside, $\mathrm{pl}$ - plagioclase, $\mathrm{g}$ - garnet, $\mathrm{q}$ - quartz, ru rutile, ilm - ilmenite, ep - epidote, $\mathrm{H}_{2} \mathrm{O}$ - water. Numbered fields: 1 - hb di pl ilm ru g q 4V, 2 - hb di pl ilm ru g q $\mathrm{H}_{2} \mathrm{O} 3 \mathrm{~V}, 3-\mathrm{hb}$ di ru g q $\mathrm{H}_{2} \mathrm{O}$ $5 \mathrm{~V}, 4-\mathrm{hb}$ di pl ru g q ep $\mathrm{H}_{2} \mathrm{O} 3 \mathrm{~V}, 5-\mathrm{hb}$ di ru g q ep $\mathrm{H}_{2} \mathrm{O} 4 \mathrm{~V}, 6-\mathrm{hb}$ o ru g q ep act $\mathrm{H}_{2} \mathrm{O} 3 \mathrm{~V}, 7-\mathrm{hb}$ di pl g ru ilm $\mathrm{H}_{2} \mathrm{O} 4 \mathrm{~V}(\mathrm{~V}=$ field variance). 
contains more minor and accessory minerals. The calculation of the P-T conditions using the conventional Jd-in-Cpx barometer (Gasparik 1984) yielded a minimum pressure of $\sim 1.8 \mathrm{GPa}$. Using the thermometers after Krogh (1988) and Ganguly et al. (1996) combined with the Holland (1980) barometer, the results for this sample correspond to $640^{\circ} \mathrm{C} / 2.0$ and $890^{\circ} \mathrm{C} / 2.3 \mathrm{GPa}$ for two different Grt-Cpx couples, resp. $830^{\circ} \mathrm{C} / 2.25 \mathrm{GPa}$, with Krogh's temperature values systematically lower (Fig. 8). The results are rather exceptional for the KHC core, but generally correspond to the data for the Běstvina Unit published, for instance, by Medaris et al. $(1998,2005)$.

The assemblage with kyanite allows an application of the geothermobarometer designed for Grt-Cpx-Qtz/ Co-Ky-Phe eclogites (Ravna and Terry 2004). Using this method, we reach $761^{\circ} \mathrm{C}$ and UHP pressures above $4.3 \mathrm{GPa}$ for the Bořetice sample KMV95, values rather acceptable for such an extreme rock associated with a garnet peridotite. For comparison, this method was applied also to the kyanite eclogite KMV103 from Spačice-Doubrava, and resulting values correspond to $753^{\circ} \mathrm{C}$ and $2.73 \mathrm{GPa}$. Calibration errors of $\pm 85^{\circ} \mathrm{C}$ and $\pm 0.35 \mathrm{GPa}$ for the phengite-free mineral assemblage should be considered.

\subsubsection{Thermodynamic modelling of the KHC eclogite from Roztěž}

The eclogites from the inner KHC zone generally display a good state of preservation of the HP mineral assemblage. One of the best-preserved samples is the eclogite from Roztěž (KMV118).

The mineral assemblage of this eclogite was used for subsequent estimation of the $\mathrm{P}-\mathrm{T}$ conditions using a P-T pseudosection calculated for its bulk-rock composition. The P-T conditions of the sequence of metamorphic events were specified by intersection of the $X_{\mathrm{Ca}} \sim \mathrm{Z}(\mathrm{g})$ $=[\mathrm{CaO} /(\mathrm{CaO}+\mathrm{FeO}+\mathrm{MgO}+\mathrm{MnO})]$ and $\mathrm{X}_{\mathrm{Fe}} \sim \mathrm{x}(\mathrm{g})=$ $[\mathrm{FeO} /(\mathrm{FeO}+\mathrm{MgO})]$ isopleths of garnet. The compositional garnet profile (core $\rightarrow$ inner zone $\rightarrow$ outer rim: $\mathrm{Grs}_{31 \rightarrow 28 \rightarrow 19} \operatorname{Prp}_{18 \rightarrow 22 \rightarrow 26} \mathrm{Alm}_{42 \rightarrow 44 \rightarrow 50} \operatorname{Sps}_{4 \rightarrow 1 \rightarrow 1} \mathrm{X}_{\mathrm{Fe} 70 \rightarrow 66 \rightarrow 65}$ ) is depicted in Fig. 5a and the corresponding data given in Tab. 3 .

It is assumed that the mineral assemblage with plagioclase and amphibole preserved in the garnet core reflects the metamorphic conditions at the beginning of a prograde path. In the pseudosection (Fig. 9), this assemblage corresponds to the Hbl-Di-Pl-Ilm-Grt-Qtz stability field at approx. $0.8 \mathrm{GPa}$ and $600^{\circ} \mathrm{C}$. The core grossular values $\left(\mathrm{X}_{\mathrm{Ca}}=31\right)$ plot in the LP/LT (Hbl-Di-Pl-Ilm-Grt-Qtz) stability field within the $\mathrm{X}_{\mathrm{Fe}}=82-88$ interval. They do not intersect the measured core values of $X_{\mathrm{Fe}}=70$ (Fig. 9) probably due to variation in the $\mathrm{Fe}$ content in the garnet core during diffusion-related processes. Considering the presence of plagioclase inclusions, it could be assumed that the garnet started to grow at plagioclase stability conditions, below $1.15 \mathrm{GPa}$.

Following the prograde path, the $\mathrm{X}_{\mathrm{Fe}}$ and $\mathrm{X}_{\mathrm{Ca}}$ isopleths intersect in the Hbl-Omp-Rt-Grt-Qtz-Ep- $\mathrm{H}_{2} \mathrm{O}$ stability field at c. $1.75 \mathrm{GPa}$ and $630{ }^{\circ} \mathrm{C}$ (Fig. 9, point A). This trend is supported by an occasional presence of epidote-clinozoisite inclusions at the boundary between core and inner zone. The constructed course of the P-T path crosses the epidote stability field during pressure increase. Thus, the garnet core composition shows an evidence for a prograde part of the P-T path to the point A at relatively low temperature $\left(600-630{ }^{\circ} \mathrm{C}\right)$.

The second, inner zone of the garnet includes the relict assemblage corresponding to the peak Omp-Rt-Grt-Qtz$\mathrm{H}_{2} \mathrm{O}$ (liq) stability field. The grossular values in this inner zone yield $\mathrm{X}_{\mathrm{Ca}}=28$. This entire stability field is characterized by this latter value of the grossular isopleth, and thus the maximum P-T conditions can be estimated only from inner zone $\mathrm{X}_{\mathrm{Fe}}$ values $\left(\mathrm{X}_{\mathrm{Fe}}=65-66\right)$. The relevant garnet isopleths pass within the interval of $600-650{ }^{\circ} \mathrm{C}$ from $2.2 \mathrm{GPa}$ presumably to even higher pressures, as is supported by conventional geothermobarometry (Fig. 9, heavy dotted line B).

The third outer zone with kelyphite-forming reaction representing the result of decompression under MP/HT conditions falls into the Hbl-Di-Pl-Grt-Ilm- $\mathrm{H}_{2} \mathrm{O}$ stability field at $1.25 \mathrm{GPa}$ and $890^{\circ} \mathrm{C}$, and also agrees with the intersection of the outer rim garnet isopleths $\left(\mathrm{X}_{\mathrm{Ca}}=19\right.$, $\mathrm{X}_{\mathrm{Fe}}=65$ ) in the pseudosection (Fig. 9, point C).

\section{Conclusions}

The current work summarizes the information on the occurrences of numerous newly described, relatively small lenses of MP-HP-UHP metabasic rocks in the inner part of the KHC, and compares them with similar lithologies in the Běstvina Unit and at the adjacent northern margin of the Moldanubian Zone.

The P-T path of eclogite from the new Roztěž locality in the KHC was estimated by means of the pseudosection modelling supported by conventional thermobarometry. The Roztěž eclogite indicates minimum pressures above 2.15-2.3 GPa and temperatures of $600-650{ }^{\circ} \mathrm{C}$ reached during the prograde part of metamorphism. The peak of metamorphism is bracketed by $\mathrm{T} \sim 650-900^{\circ} \mathrm{C}$, including a stage of decompressional, higher tempered granulitefacies overprint.

The jadeite-rich clinopyroxene in the kyanite-bearing eclogite KMV95 from Bořetice indicates even higher pressures than those inferred from Roztěž eclogite and from the Běstvina Unit $\left(761^{\circ} \mathrm{C} / 4.3 \mathrm{GPa}\right.$, Ravna and Terry 2004). The eclogite found in blocks displays similar relict 
HP deformational structures as garnet peridotite cropping out nearby, so the genetic relationship is probably close. When we compare whole-rock composition of this $\mathrm{Ky}$ eclogite and garnet pyroxenite from peridotite from Bečváry, there are substantial differences in $\mathrm{MgO}, \mathrm{Al}_{2} \mathrm{O}_{3}$, $\mathrm{Na}_{2} \mathrm{O}$ and $\mathrm{CaO}$ contents.

Although partially affected by thermal overprint and retrogression, the eclogite samples from the inner KHC (Bořetice outcrop, Roztěž and Poličany) clearly indicate a prograde metamorphic path. Such record is missing in the studied eclogites from the Moldanubian Zone and its Gföhl Unit.

The major-element composition exhibits differences in the HP rock group and the previously described garnet pyroxenite-forming layers in garnet peridotite from Bečváry.

Eclogites in the inner KHC occur along with garnet peridotites in the parent mylonitized gneisses and mica schists. The rock assemblage indicates presence of deep-seated tectonic shear zones that incorporated the lower-crustal and mantle-derived rock bodies. This is a new finding namely for the Malešov-Roztěž eclogite occurrence.

Three eclogites from the northern margin of the Moldanubian Zone S of Chotěboř (especially the Bída and Borovský Creek localities) exhibit geochemical characteristics similar to the Mg-rich eclogites from the Běstvina Unit and the inner part of the KHC. A highpressure mineral assemblage and the peak metamorphic conditions recorded in these eclogites correspond, on an average, to the highest pressures found in this part of the $\mathrm{MZ}$ and adjacent $\mathrm{KHC}$ (minimum $\mathrm{P}>2.0 \mathrm{GPa}, \mathrm{T}=$ $700-750^{\circ} \mathrm{C}$ ). These eclogites are associated with $\mathrm{Cpx}-$ granulites and $\mathrm{Ky}-\mathrm{Grt}$ gneisses, and altogether indicate the presence of a refoliated and so far hidden local highgrade domain in this part of the MZ.

The study provides also new data on other types of metabasites - Cpx-bearing amphibolites - and compares their chemical and mineralogical composition with the HP group. Cpx-bearing garnet amphibolite from Doubravčany South in the inner part of the KHC probably belongs to another metabasite group enriched in $\mathrm{Fe}$, with compositional affinity to MP-MT calc-silicate rocks (see Pertoldová et al. 2007).

Based on comparison of the eclogites and amphibolites, two types of metabasites in the KHC and the adjacent $\mathrm{MZ}$ can be distinguished. The zones of prevailingly conform lenses of calc-alkaline amphibolites of volcanosedimentary origin and MP-MT metamorphic record related to the outer Mica Schist Unit can be distinguished from the $\mathrm{Fe}-$ and $\mathrm{Mg}$ - rich tholeiitic series associated with mantle rocks and occasionally also with felsic to pyroxene-bearing granulites in the Běstvina Unit and the inner high-grade part of the KHC. Another newly described HP metabasite from Tři Dvory east of Kolín is probably an eclogitized two-pyroxene metagabbro. The eclogite assemblage indicates somewhat lower pressures than the other HP rocks - around 1.2-1.5 GPa. The rock might be related to the coronitic metabasites reported from the Svatý Krríž Massif (Holub and Munschi 1984).

Acknowledgments The paper stems from fieldwork of Milan Fišera, who mapped the northern part of the KHC, namely the Plaňany and Běstvina units, and found numerous remarkable localities. The occurrence of kyanite eclogite near Bořetice was first noticed by Zdeněk Běhal, who brought some samples to the first author; his deep knowledge of garnetiferous rocks in the area and cooperation are highly appreciated.

The work was supported by scientific project "Correlation of exotic lithologies along the NW margin of the Moldanubian Unit" undertaken by the Czech Geological Survey (Internal project No. 6380), and the analytical work was co-financed by the ARTEC Research Centre coordinated by TU Liberec. The authors are extremely grateful for many helpful comments by the Journal's reviewers M. Svojtka and L. G. Medaris that helped to improve significantly the current manuscript.

Electronic supplementary material. The GPS coordinates of the studied samples, and the chemical data (Tabs 2-4) are available online at the Journal web site (http://dx.doi. org/10.3190/jgeosci.047).

\section{References}

Beard BL, Medaris LG JR, Johnson CM, Brueckner HK, MísAŘ Z (1992) Petrogenesis of Variscan high-temperature group A eclogites from the Moldanubian Zone of the Bohemian Massif, Czechoslovakia. Contrib Mineral Petrol 111: 468-483

Diener JFA, Powell R, White RW, Holland TJB (2007) A new thermodynamic model for clino- and orthoamphiboles in $\mathrm{Na}_{2} \mathrm{O}-\mathrm{CaO}-\mathrm{FeO}-\mathrm{MgO}-\mathrm{Al}_{2} \mathrm{O}_{3}-\mathrm{SiO}_{2}-\mathrm{H}_{2} \mathrm{O}-\mathrm{O}$. J Metamorph Geol 25: 631-656

FARYAD SW (2009) The Kutná Hora Complex (Moldanubian Zone, Bohemian Massif): a composite of crustal and mantle rocks subducted to HP/UHP conditions. Lithos 109: 193-208

FIŠERA M (1977) Geology and petrology of the Kutná Hora Unit west of Kolín. Czech Geological Survey Research Papers 16: 19-31 (in Czech)

FIŠERA M (1981) Geological and petrographic relationships in the Plaňany area. Geological Survey Research Papers 26: 5-42 (in Czech)

Ganguly J, Cheng W, Tirone M (1996) Thermodynamics of alumosilicate garnet solution: new experimental data, 
an optimised model and thermodynamic application. Contrib Mineral Petrol 126: 137-151

GASPARIK T (1984) Experimentally determined stability of clinopyroxene + garnet + corundum in the system $\mathrm{CaO}$ $\mathrm{MgO}-\mathrm{Al}_{2} \mathrm{O}_{3}-\mathrm{SiO}_{2}$. Amer Miner 69: 1025-1035

GaSPARIK T, LindSLEY DH (1980) Phase equilibria at high pressure of pyroxenes containing monovalent and trivalent ions. In: PrewitT CT (ed) Pyroxenes. Mineralogical Society of America Reviews in Mineralogy 7: 309-339

Green ECR, Holland TJB, Powell R (2007) An orderdisorder model for omphacitic pyroxenes in the system jadeite-diopside-hedenbergite-acmite, with applications to eclogite rocks. Amer Miner 92: 1181-1189

Holland TJB (1980) The reaction albite $=$ jadeite + quartz determined experimentally in the range $600-1200{ }^{\circ} \mathrm{C}$. Amer Miner 65: 129-134

Holland TJB, Powell R (1998) An internally consistent thermodynamic dataset for phases of petrological interest. J Metamorph Geol 16: 309-343

Holland TJB, Powell R (2003) Activity-composition relations for phases in petrological calculations: an asymmetric multicomponent formulation. Contrib Mineral Petrol 145: 492-501

Holland TJB, Baker JM, Powell R (1998) Mixing properties and activity-composition relationships of chlorites in the system $\mathrm{MgO}-\mathrm{FeO}-\mathrm{Al}_{2} \mathrm{O}_{3}-\mathrm{SiO}_{2}-\mathrm{H}_{2} \mathrm{O}$. Eur J Mineral 10: 395-406

Holub FV, Munschi RL (1984) Subsolidus reaction rims between the olivine and calcic plagioclase in the Svatý Kř́̌ž Massif, eastern Bohemia. Krystalinikum 17: 47-58

IRVINE TN, BARAGAR WRA (1971) A guide to the chemical classification of the common volcanic rocks. Canad J Earth Sci 8: 523-548

JANOUŠEK V, FARROW CM, ERBAN V (2006) Interpretation of whole-rock geochemical data in igneous geochemistry: introducing Geochemical Data Toolkit (GCDkit). J Petrol 47: $1255-1259$

JENSEN LS (1976) A new cation plot for classifying subalkalic volcanic rocks. Ontario Geological Survey Miscellaneous Paper 66: 1-22

KACHLíK V (1999) Relationship between Moldanubicum, the Kutná Hora Crystalline Unit and Bohemicum (Central Bohemia, Czech Republic): a result of polyphase Variscan nappe tectonics. J Czech Geol Soc 44: 201-291

Kratochvíl F (1952) On some amphibolites on the special map sheet Kutná Hora (4054). Sbor St Úst Geol 14: 291-307 (in Czech)

KroGH EJ (1988) The garnet-clinopyroxene Fe-Mg geothermometer - a reinterpretation of existing experimental data. Contrib Mineral Petrol 99: 44-48

Leake EB, Woolley AR, Arps ES, Birch WD, Gilbert ChM., Grice JD, Hawthorne FC, Kato A., Kisch HJ, Krivovichev, Linthout K, Laird J, Mandarino JA, Maresch WV, Nickel EH, Rock N, Schumacher JC,
Smith DC, Stephenson N, Ungaretti B, Whittaker EJW, YouzHI G (1997) Nomenclature of amphiboles: report of the Subcommittee on amphiboles of the International Mineralogical Association, Commission on new minerals and mineral names. Canad Mineral 35: 219-246

LOSERT J (1967) Contribution to the problem of the PreAssynthian tectogenesis and metamorphism in the Moldanubicum of the Bohemian Massif. Krystalinikum 5: 61-84

MacheK M, Faryad SW, Ulrich S (2006) Structural position and metamorphism of peridotite and eclogite bodies within granulite in the Bestvina unit, Bohemian Massif. Geolines 20: 86-87

Matte P, Maluski H, Rajlich P, Franke W (1990). Terrane boundaries in the Bohemian Massif: results of large-scale Variscan shearing. Tectonophysics 177: 151-170

Mazur S, Aleksandrowski P, Szczepanski J (2005) The presumed Teplá-Barrandian/Moldanubian terrane boundary in the Orlica Mountains (Sudetes, Bohemian Massif). Structural and petrological characteristics. Lithos 82: $85-112$

Medaris LG Jr, Beard BL, Johnson CM, Valley JW, SPicuzZa MJ, JelíneK E, Mísař Z (1995a) Garnet pyroxenite and eclogite in the Bohemian Massif: geochemical evidence for Variscan recycling of subducted lithosphere. Geol Rundsch 84: 489-505

Medaris LG JR, Jelínek E, Mísař Z (1995b) Czech eclogites: terrane setting and implications for Variscan tectonic evolution of the Bohemian Massif. Eur J Mineral 7: 7-28

Medaris LG Jr, Fournelle JH, Ghent ED, Jelínek E, Mísař Z (1998) Prograde eclogite in the Gföhl Nappe, Czech Republic: new evidence on Variscan high-pressure metamorphism. J Metamorph Geol 16: 563-576

Medaris LG JR, Wang H, Jelínek E, Mihaljevič M, Jakeš P (2005) Characteristics and origins of diverse Variscan peridotites in the Gföhl Nappe, Bohemian Massif, Czech Republic. Lithos 82: 1-23

Medaris LG JR, BeARd BL, JelíneK E (2006) Mantle-derived, UHP garnet pyroxenite and eclogite in the Moldanubian Gföhl Nappe, Bohemian Massif: a geochemical review, new P-T determinations, and tectonic interpretation. Int Geol Rev 48: 765-777

Nahodilová R, Faryad SW, Pertoldová J, Konopásek J, ŠTĚDRÁ V (2006) Contrasting metamorphic evolution of HP rocks in the Gföhl Unit of the Kutná Hora Crystalline Complex and the Moldanubian Zone in Austria. Geolines 20: 98-99

NovÁK JK, VRBová H (1994) Petrogenesis and geochemistry of mafic rocks from the Kutná Hora Crystalline Complex and the neighbouring part of the Rataje Micaschist Zone. Geolines 4: 1-41

Onďíí J, Holub M, Mísař M, Moupic Z, Scharmová M, ŠTemberk J, ŠpaČeK J, ZÁliš J (1996) The Strážek Unit-North. Final report on the uranium ores exploration. 
Geam Dolní Rožínka, DIAMO Stráž pod Ralskem. Unpublished manuscript Geofond, Prague

PADĚrA K (1972) Griquaites in the Moldanubicum of the Bohemian Massif. In: ZoubeK V (ed) Upper Mantle Project Programme in Czechoslovakia 1962-1970. Academia, Prague, pp 51-59

Pertoldová J, Buriánek D, Hrdličková K, Čapek D, Čopjaková R, Schulmannová, B, Dušek K, Haloda J, Hanžl P, Konopásek J, KopačKová V, Košuličová M, Malec J, Nahodilová R, Soejono I, Sulovský P, ŠKoda R, ŠTĚdRÁ V, TÁborskÝ Z, TaJČManová L, TÝcová P, Verner K, Veselovský F, Vondrovic L, Vrána S, ZavŘelová A, Žáč́ová E, Šrámek J, Melichar R (2007) Reconnaissance of lithologically contrasting rocks in the crystalline units at the north-eastern edge of the Moldanubian Zone - connection to basic geological mapping at the scale of 1:25 000. Unpublished report, Czech Geological Survey, Prague (in Czech)

Pertoldová J, Týcová P, Verner K, Košuličová M, Pertold Z, KošLer J, KonopáseK J, Pudilová M (2009) Metamorphic history of skarns, origin of their protolith and implications for genetic interpretation; an example from three units of the Bohemian Massif. J Geosci 54: 101-134

Pouba Z, Fiala J, Paděra K (1987) The granulite body near Běstvina in the Železné Hory Mts. Čas Min Geol 32: 73-78

Powell R, Holland T, Worley BA (1998) Calculating phase diagrams involving solid solutions via non-linear equations, with examples using THERMOCALC. J Metamorph Geol 16: 577-588

RAVNA EJK, TERRY MP (2004) Geothermobarometry of UHP and HP eclogites and schists - an evaluation of equilibria among garnet clinopyroxene-kyanite-phengite-coesite/ quartz. J Metamorph Geol 22: 579-592

Reche J, Martinez FJ (1996) GPT: an Excel spreadsheet for thermobarometric calculations in metapelitic rocks. Comput and Geosci 22: 775-784

Schulmann K, Kröner A, Hegner E, Wendt I, Konopásek J, LEXA O, ŚTíPSKÁ P (2005) Chronological constraints on the pre-orogenic history, burial and exhumation of deepseated rocks along the eastern margin of the Variscan orogen, Bohemian Massif, Czech Republic. Amer J Sci 305: 407-448

Sobolev VN, McCammon CA, Taylor LA, Snyder GA, Sobolev NV (1999) Precise Mössbauer milliprobe determination of ferric iron in rock-forming minerals and limitations of electron microprobe analysis. Amer Miner 84: 78-85

STURM R (2002) PX-NOM - an interactive spreadsheet program for the computation of pyroxene analyses derived from the electron microprobe. Comput and Geosci 28 : 473-483
SyneK J (1991) Formation of sheath folds and reorientation of lineations in the western part of the Kutná Hora Crystalline Unit. Věst Ústř Úst Geol 66: 75-84

Synek J, Oliveriová D (1993) Terrane character of the northeast margin of the Moldanubian Zone: the Kutná Hora Crystalline Complex, Bohemian Massif. Geol Rundsch 82: $566-582$

ŠTĚDRÁ V, ED (2009) Geological map of the Czech Republic on scale $1: 25$ 000, sheet Ždírec nad Doubravou 23-221, with explanations. Czech Geological Survey, Prague

ŠTĚdRÁ V, NAHODILOVÁ R, BURIÁNKOVÁ K (2007) Eclogites and related metabasic rocks. In: Pertoldová J, BuriáneK D, Hrdličková K, Čapek D, Čopjaková R, SchulmannOVÁ, B, Dušek K, Haloda J, HaNŽl P, KonopáseK J, KopačKová V, Košuličová M, Malec J, Nahodilová R, Soejono I, Sulovský P, ŠKoda R, Štědrá V, TÁborskÝ Z, Tajčmanová L, TÝcová P, Verner K, Veselovský F, Vondrovic L, VRána S, ZavŘelová A, ŽáčKová E, ŠrámeK J, Melichar R (2007) Reconnaissance of lithologically contrasting rocks in the crystalline units at the north-eastern edge of the Moldanubia Zone - connection to basic geological mapping on the scale of 1:25000. Unpublished report, Czech Geological Survey, Prague, pp 162-188 (in Czech)

ŠTísskÁ P, Powell R (2005) Constraining the P-T path of a MORB-type eclogite using pseudosections, garnet zoning and garnet-clinopyroxene thermometry: an example from the Bohemian Massif. J Metamorph Geol 23: 725-743.

VRÁNA S, ŠTĚDRÁ V, FišERA M (2005) Petrology and geochemistry of the Běstvina granulite body metamorphosed under eclogite facies conditions, Czech Republic. J Czech Geol Soc 50: 95-106

VRÁNA S, ŠTĚDRÁ V, NAHODILOVÁ R (2009) Geochemistry and petrology of high-pressure kyanite-garnet-albite-K-feldspar felsic gneisses and granulites from the Kutná Hora Complex, Bohemian Massif. J Geosci 54: 159-179

White RW, Powell R, Holland TJB, Worley BA (2000) The effect of $\mathrm{TiO}_{2}$ and $\mathrm{Fe}_{2} \mathrm{O}_{3}$ on metapelitic assemblages at greenschist and amphibolite facies conditions: mineral equilibria calculations in the system $\mathrm{K}_{2} \mathrm{O}-\mathrm{FeO}-\mathrm{MgO}-$ $\mathrm{Al}_{2} \mathrm{O}_{3}-\mathrm{SiO}_{2}-\mathrm{H}_{2} \mathrm{O}-\mathrm{TiO}_{2}-\mathrm{Fe}_{2} \mathrm{O}_{3}$. J Metamorph Geol 18: 497-511

White RW, Powell R, Clarke GL (2002) The interpretation of reaction textures in Fe-rich metapelitic granulites of the Musgrave Block, central Australia: constraints from mineral equilibria calculations in the system $\mathrm{K}_{2} \mathrm{O}-\mathrm{FeO}-$ $\mathrm{MgO}-\mathrm{Al}_{2} \mathrm{O}_{3}-\mathrm{SiO}_{2}-\mathrm{H}_{2} \mathrm{O}-\mathrm{TiO}_{2}-\mathrm{Fe}_{2} \mathrm{O}_{3}$. J Metamorph Geol 20: 41-55

White RW, Powell R, Holland TJB (2007) Progress relating to calculation of partial melting equilibria for metapelites. J Metamorph Geol 25: 511-527 